\title{
THE ROLE OF DEPORTATION IN THE INCARCERATION OF IMMIGRANTS
}

\author{
Kristin F. Butcher \\ Anne Morrison Piehl \\ Working Paper 6974 \\ http://www.nber.org/papers/w6974 \\ NATIONAL BUREAU OF ECONOMIC RESEARCH \\ 1050 Massachusetts Avenue \\ Cambridge, MA 02138 \\ February 1999
}

\begin{abstract}
The authors are grateful to Daniel Kanstroom and David Cory for help with interpretation of the immigration laws. We thank John Berecochea and the Research Branch of the California Department of Corrections for access to and assistance with the data. Our findings should not be construed as representing the views of the State of California or the Department of Corrections. Mark Fassold provided excellent research assistance. We appreciate helpful comments from David Card, Jeffrey Grogger, Hilary Hoynes, Stephen Legomsky, Gilbert Metcalf, Dan Noelle and seminar participants at UC-Berkeley, Tufts University, and at the NBER's conference on immigration. Butcher appreciates the support from the Industrial Relations Section at Princeton. Piehl appreciates the support of the Robert Wood Johnson Foundation. All errors are our own. Any views expressed in this paper are those of the author only and not those of the National Bureau of Economic Research.
\end{abstract}

- 1999 by Kristin F. Butcher and Anne Morrison Piehl. All rights reserved. Short sections of text, not to exceed two paragraphs, may be quoted without explicit permission provided that full credit, including ${ }^{(0)}$ notice, is given to the source. 
The Role of Deportation in the Incarceration of Immigrants

Kristin F. Butcher and Anne Morrison Piehl

NBER Working Paper No. 6974

February 1999

JEL No. K42, J18, H79

\section{ABSTRACT}

Using data on all new admissions to California state prisons in 1986, 1990, and 1996, we find that the foreign born have a very different offense mix from native-born inmates, with foreigners much more likely to be serving time for drug offenses. We document and discuss many of the substantial changes in the enforcement environment over this period, including the war on drugs, changes in public law expanding the classes eligible for deportation, and increases in the level of resources appropriated for enforcement activities targeting deportable aliens. These developments have resulted in much greater attention by the Immigration and Naturalization Service to the incarceration of the foreign born. By 1996, the definition of "deportable" was such that it covered essentially all noncitizens in the California prison system. Throughout the period, those foreign-born inmates designated by the California Department of Corrections to be released to INS custody serve substantially (6-12 percent) longer terms (conditional upon sentence length) than natives or other "similar" foreigners. These longer terms of incarceration impose substantial costs on the state.

Kristin F. Butcher

Department of Economics

145 Carney Hall

Boston College

Chestnut Hill, MA 02167

kristin.butcher@bc.edu
Anne Morrison Piehl

140 Warren Hall

University of California, Berkeley

Berkeley, CA 94720-7360

and NBER

piehl@socrates.berkeley.edu 


\section{Introduction}

The small empirical literature on the effects of immigration on crime and criminal justice has produced several stylized facts. While any amount of immigration must increase the total numbers of crimes in the United States, Butcher and Piehl (1998b) reported that increasing immigration does not increase crime rates in the largest U.S. cities. In an analysis of the effects of immigration on the behavior of the native born, Grogger (1998) showed that there did not appear to be "spillovers" from the labor market competition of immigrants onto the criminality of African-American youth. Butcher and Piehl (1998a) found that more recent immigrants appear to be less criminal (relative to the native born) than earlier arrivals. This is in spite of the fact that recent immigrants fare relatively poorly in the labor market. Furthermore, the same paper documented that immigrants were much less likely to be institutionalized than one would expect given their relatively low levels of education.

This literature has left unanswered many questions relevant to public policy about immigration and, in particular, about immigrants in the criminal justice system. Policies toward immigrants who commit crimes in the United States may affect which immigrants choose to enter the country, the extent to which immigrants become naturalized citizens, and the extent to which immigrants in the country engage in illegal activity. While these are important topics, there are more basic questions about current conditions about which we know very little. Do immigrants and natives commit similar types of offenses? Are the foreign born treated differently than natives within the criminal justice system? And, if so, how does that affect costs? In this paper, we address these questions while documenting the legal consequences of criminal activity for immigrants and how these consequences have changed over time.

There are many reasons to be concerned about the treatment of criminal aliens in the United States. First, the past 25 years have seen the largest numbers of immigrants since the early 1900s and the quadrupling of the prison population. Consequently, the absolute number of incarcerated immigrants is large and growing. Second, Congressional legislation has dramatically expanded the types of criminal acts which "qualify" noncitizens for deportation while at the same time increasing the resources for identifying 
and processing criminal aliens. These Acts impose conditions on the states, which have traditionally maintained primary responsibility for law enforcement. The consequences of these laws, intended or not, are considerable. Third, several court cases have restricted the use of certain modes of punishment for noncitizens, e.g., early release and low-security facilities, which are widely used for citizens. While not everyone will be concerned about horizontal equity associated with differential punishment by nativity for similar criminal acts, concern about the efficient use of the public purse is widespread. To the extent that costs of the restrictions on the terms of confinement are not offset by savings due to increased vigilance in implementing deportation, the increase in the use of public resources in the incarceration of aliens could be substantial.

We analyze the experience of one jurisdiction (California) particularly affected by the costs of incarcerating foreign-born inmates. While California may not be representative of the nation, it is emblematic of this particular social policy issue. Using data on all new admissions to state prisons for three points in time, we analyze the offenses of the foreign born and of natives. We find that the foreign born are very different from native-born inmates in terms of their crime mix, with foreigners much more likely to be serving time for drug offenses. The Immigration and Naturalization Service (INS) appears to be much more involved with incarcerated foreign born in 1996 than it was in 1986. This is the result of the war on drugs as well as changes in public law and in the level of resources appropriated for enforcement activities targeting deportable aliens. Inmates designated by the California Department of Corrections (CADOC) to be released to INS custody (called "INS holds") had sentences about 40 percent longer than natives in 1986, which may reflect that those foreigners had committed more serious offenses. By 1996, the definition of "deportable" was expanded such that it should cover all noncitizens in the CADOC. We find that, even at the end of the period, those foreign born with INS holds served substantially longer terms (conditional upon sentence length) than natives or other "similar" foreigners. These longer terms of incarceration impose substantial costs on the state. 
The paper is organized as follows. Section II compares foreign-born inmates to native-born inmates in California. Section III considers federal jurisdiction. Section IV describes the legal and law enforcement environment with respect to noncitizens involved in criminal activity. Section V contains a multivariate analysis of criminal justice outcomes in California, and Section VI concludes.

\section{California Inmates: Foreign Born and Native Born}

This section introduces the data used in the paper and provides a description of inmates in California prisons over time, focusing on the differences between foreign-born and U.S.-born offenders.

\section{A. California Department of Corrections Data}

We use administrative data from the CADOC from 1986, 1990, and 1996. These are administrative data used to keep track of inmates while they are in the custody of the Department of Corrections. The admission cohorts contain all individuals who were admitted to the prison system with new crimes in each year. ${ }^{1}$ These data were constructed from the CADOC master file as of June 1997, so we observe whether an inmate was released by that date. We focus on the subsample of offenders with completed terms when we analyze differences in time served across groups.

Because the purpose of these data is to keep track of inmates, the number of variables included in the master data set is enormous and rich in details about the inmates' appearance (e.g., hair and eye color) and movements (e.g., to and from the dentist). However, many of these variables are not of interest here and much information that we would like is unavailable. The available demographic data include the inmate's age at admission, race and ethnicity, and country of origin. Additionally, we have information on the principal commitment offense category, the length of sentence, and the actual time served for those who are released during the period. 
There is potentially important information that we do not have, most notably criminal history. The data also contain no information on educational attainment, which for some purposes is a useful control variable. Also, we have no information on pre-sentencing confinement or behavior in prison, both of which could impact the time actually served for a particular sentence length. We discuss the impact of these data shortcomings on interpretation as they arise.

While we have information on country of origin, we have no information on citizenship status. In the labor economics literature, it is common to use the terms "foreign born" and "immigrant" interchangeably. Here, however, it is important to recognize the differences. The foreign born who have become citizens are not subject to deportation, so one would not expect changes in policies surrounding deportation to affect their criminal justice outcomes. Secondly, some of the foreign-born inmates may be individuals who were expecting to be in the United States temporarily (e.g., tourists or business travelers), some of whom may have entered for the purpose of committing a crime, and are therefore not "immigrants."

When we analyze those inmates who have been released, we break the foreign born into three groups, depending on their status with the INS. When a foreigner is sentenced, the INS is supposed to begin proceedings to determine his or her deportation status. If the INS either determines that the individual is deportable, or is continuing its investigation into whether he or she is deportable, an INS "hold" is placed on that person. Our data contain information on whether someone is in this "INS hold" category. For some individuals, an INS hold was placed on them after their release date, because the INS did not discover until late in the process that the person was potentially deportable. We label those with INS holds prior to their release from prison as "INS hold." Those with holds after their release date are labeled "late holds." Those with no INS holds on their records are labeled "no hold."

We dropped a number of observations from the sample because of missing or invalid data. Individuals who had an invalid year for admission or release, those who were released on the same day as 
they were admitted, and people who were sentenced for less than one year were dropped. This latter exclusion is because individuals are only supposed to be remanded to the prison system for terms of one year and higher (others are remanded to jails operated by counties). "Lifers" - those in for murder - were excluded because they do not have determinate sentences. ${ }^{3}$

We further excluded some individuals because of difficulty in interpreting their information. We dropped individuals whose principal commitment offense was "escape" since we do not have information on the crime that landed them in prison in the first place. We also deleted people who served more than 100 percent of their sentence and those whose sentencing date was later than their admission date. The first group is likely to be those with extremely bad behavior while in prison. The latter group is those who were sentenced for an additional offense while in prison. Since we have no information on behavior in prison, these individuals complicate the analysis. Finally, we dropped individuals born in outlying areas of the United States (Puerto Rico), and the native born who had an INS hold placed on their record, since neither fit cleanly into the groups under study. ${ }^{4}$ In all of the subsamples we analyze, only three to four percent are lost because of these sample restrictions.

\section{B. Descriptive Statistics}

Table 1a shows information for those men admitted in 1986, 1990, and 1996. The number of men admitted in 1986 was approximately 21,000. By 1996, the number of new admissions had increased to about 39,000. The fraction of the admission cohorts that was foreign born also increases, rising from about 19 percent in 1986, to 25 percent in 1990, to 27 percent in 1996. While foreign-born men represent a sizeable fraction of the flows into prison in California, they also represent a large fraction of the population overall. In 1980, the foreign born comprised about 18 percent of the 18-40 year old male population (roughly comparable to the group most likely to be in prison); by 1990, they had risen to about 24 percent of this population. ${ }^{5}$ So foreign-born men's representation in the admission flows into prison in 
California is roughly equal to their representation in the state as a whole, despite the fact that based on their average education, for example, one might expect them to have higher incarceration rates. (See Butcher and Piehl, 1998a).

There are substantial differences between the characteristics of native-born and foreign-born men in these admission cohorts. Foreign-born men are slightly younger than the native-born, and this difference increases slightly over the time periods studied here. There are striking differences in the race and ethnicity categories, and these differences increase over time. Among the native-born, the percent white nonHispanic was 37 percent in 1986 and rose slightly to 40 percent in 1996. Among the foreign born, the overwhelming majority of inmates are Hispanic. In 1986, Hispanics represent 72 percent of the foreignborn inmates admitted. This rose to 85 percent in 1990, and 87 percent in 1996. Hispanics, both native and foreign born, were predominantly of Mexican descent.

One of the unanswered questions in the literature on immigration and crime is whether the foreign born and natives commit different types of crimes. ${ }^{6}$ These data allow us to, at least partially, address this question. These data, of course, do not allow us to answer questions about those who commit crimes but are never apprehended or convicted. To the extent that there are differences in apprehension and conviction rates between the foreign born and natives, these data will give a distorted view of the crimes committed by these two groups.

There are statistically significant differences, in all years of admission data, in the types of crimes for which foreigners and natives are committed to prison. The foreign born were less likely to be in prison for property and assault offenses. In 1986, they were less likely to be serving time for sex offenses. Although the fraction of the admission cohort that was incarcerated for manslaughter is low overall (and falling), the foreign born were slightly more likely to have this as their principal commitment offense. There is a striking difference in the fraction sentenced for drug offenses. In 1986, 20 percent of the natives and 33 percent of the foreign born were committed for drug offenses. By 1996, this rose to 32 percent of 
the native born and 46 percent of the foreign born. The category "drug possession" is a subset of the "drug offenses" group. The foreign born were significantly less likely in 1990 and 1996 to be incarcerated solely on possession charges.

In 1986 and 1990, foreign-born men had significantly shorter sentences than the native born. The average sentence length among the native born was 47 months in 1986, fell to 41 months in 1990, and rose again to 45 months in 1996. Among the foreign born, the average sentence length was 43 months in 1986, 40 months in 1990, and 45 months in 1996. The shorter sentences for the foreign born in 1986 and 1990 may reflect differences in the offense types. The increase in the relative sentence length up to equality with the native born by 1996 may be due to several factors: changes in the offense type or severity, changes in the enforcement and punishment of certain offenses, or changes in the treatment of immigrants per se. These possibilities are explored in section IV.

The final row of Table 1a lists the fraction of the foreign born with an INS hold on their records. As described previously, this indicates that the INS had either determined that the individual is deportable ${ }^{7}$ or was in the process of investigating his or her status. The fraction of the foreign-born population that has an INS hold on record increased dramatically over this time period, rising from approximately 30 percent in 1986, to 68 percent in 1990, to 75 percent in 1996. In addition to the proportion increasing, the swiftness with which INS hold orders are placed increased as well. In 1986, 75 percent of those inmates who would eventually have INS holds (including those for whom INS holds were filed after their release) had those holds on record within 766 days. In 1990, 75 percent of those who would eventually have INS holds placed on their records were identified within 152 days.

Table 2a gives details on the offense categories, sentence length, and actual time served for four groups: the native born and three subgroups of the foreign born. The data here are for the men admitted in 1986 and 1990, and released within six years of admission. Restricting the analysis in this way allows us comparable groups for the 1986 and 1990 admission cohorts. The vast majority of inmates serve fewer 
than six years - from 96.5 percent to 99.7 percent of our various admission cohorts. Nonetheless, these results are not generalizable to the inmate population serving the longest terms. ${ }^{8}$

Since most inmates serve fewer than six years, the means for most variables are essentially the same as in Table 1a. Here we focus on time served, but repeat some other variables so they can be compared for a consistent sample. For example, the crime mix is somewhat different from the earlier table.

The foreign born are divided into the three categories described earlier: those with no INS hold, those with an INS hold on record, and those for whom the INS hold was placed on their record after their release to parole ("late hold"). In 1986, the "INS hold" group had by far the highest sentence length, averaging 54 months. Those foreign born without holds, or those deemed deportable after release, had the lowest sentences (33 and 27 months, respectively). Under the California Determinate Sentencing Law, an inmate is supposed to serve at least 40 percent of his sentence. In practice, actual time served in prison depends on several factors. The exact amount depends on rewards for behavior in prison, often referred to as "good time." In addition, some of those admitted to prison were not able to make bail and thus were confined in county jails prior to their sentencing. These individuals may receive "credit" for this presentencing confinement and, as a result, may not serve as much time in the state system. These complications notwithstanding, the correlation between sentence length and actual time served is strong. The INS-hold foreigners served 25 months in 1986, compared to 18 months for the native born. Foreigners without INS holds served 14 months, and "late holds" served 11 months. There is also evidence that in 1986 the INS-hold foreigners were committed for more serious crimes. A higher proportion of them were incarcerated for assault, manslaughter, and sex offenses. In 1986, deportation appears to have been pursued largely for the most serious offenders.

By 1990, quite a lot changed. The immigrants with INS holds had sentences that were only slightly higher than the native born (39 months vs. 36 months). The offense distribution for the "INS holds" has changed as well. Now 54 percent were incarcerated for drug offenses, and the proportion 
incarcerated for assault has dropped well below that for the native born and slightly below that for the other groups of foreign born. The proportion committed for manslaughter fell from 9 percent in 1986 to 3.4 percent in 1990, which is below the rate for the native born. The proportion of sex offenders has also fallen below that for the native born.

In all, Tables 1a and 2a suggest that there has been a significant increase in the proportion of the foreign-born prison population that is "deportable." Table 2a suggests that the types of crimes committed by this "deportable" group has shifted from serious violent crimes to more drug offenses. Section IV below details some of the reasons this segment of the foreign-born inmate population increased so dramatically during this time period, and why the principal commitment offenses may have changed. Before moving to that section, we examine the analogous data for women.

Table $1 \mathrm{~b}$ shows the fraction foreign born, demographic information, and offense distribution for women in the 1986, 1990, and 1996 admission cohorts. Note that the sample sizes are dramatically smaller for women than for men. Although the number of incarcerated women has been increasing, by 1996 they still represented only 10 percent of the prison admissions. The next striking thing to note is the fraction foreign born: in 1986, 7 percent of the women are foreign-born, by 1996 this increased to approximately 10 percent. By 1996, foreign-born women comprised about 25 percent of the female population in California. ${ }^{9}$ It is clear that foreign-born women are vastly under represented in the inmate inflow rates. Foreigners with an INS hold on record were 18 percent of those admitted in 1986, 58 percent in 1990, and 33 percent in 1996. It is difficult to know if this fluctuation reflects changes in enforcement, changes in the underlying population, or is merely due to the small samples. The small sample sizes for women limit the extent of the analyses we can perform. Throughout the paper, we report only as much as we feel the data justify.

Relative to the male inmates, women were more likely to be incarcerated for property and drug offenses and less likely to be in for violent offenses. Within gender, however, the comparisons between 
foreign born and native born are similar. It is worth noting the large increase in the proportion of women who were committed for drug offenses. By 1996, 46 percent of the natives and 57 percent of the foreign born were admitted to prison for drug offenses.

Table $2 \mathrm{~b}$ presents means for those released within six years. There are not enough of the "INS hold" and "late hold" foreign born to break them out separately in both years. In 1990, one can see that, as with the men, the INS-hold foreigners had the longest sentence length and the longest time served. The offense distribution overall looks almost identical to the admission cohorts since very few women are truncated by our sample restriction of serving fewer than six years. As with the men, in 1990 women with INS holds were much more likely to be in for drug offenses than were other women.

Offenders who have committed crimes in California may also be incarcerated in the federal Bureau of Prisons. In order to complete the description of immigrant / non immigrant differences in incarceration, the next section considers the effect federal jurisdiction has on the inmate populations at the state level.

\section{Federal Jurisdiction}

Although state and federal jurisdiction are often analyzed in isolation, there are important reasons to consider them jointly. The responsibility for arresting, trying and punishing criminal offenders rests primarily with state and local governments, yet there are several relevant categories of offenses that fall solely under federal jurisdiction, namely immigration offenses and treason. ${ }^{10}$ Anti-immigrant advocates often overlook this definitional issue. For example, the Federation for American Immigration Reform (FAIR) in its literature often cites that 25 percent of federal inmates are noncitizens ${ }^{11}$ without noting either that the federal system incarcerates only about seven percent of the nation's inmates (Glaeser, Kessler, Piehl 1998) or that 13 percent of the noncitizens are incarcerated for immigration violations - crimes that come only under federal jurisdiction and for which citizens (generally) are not at risk. ${ }^{12}$ 
Most violations of other areas of federal law are also violations of state laws. The practical consequences of this concurrent jurisdiction have not been well researched, however. (See Glaeser, Kessler, Piehl 1998). Concurrent jurisdiction is particularly important in the area of drug crimes, since criminal acts could be prosecuted under either the relevant state law or federal law, potentially with very different consequences for the offender. ${ }^{13}$ Time served in the federal system for the same crime is likely to be twice as long as in a state prison because federal law requires that inmates serve 85 percent of their nominal sentences. Also, federal inmates generally serve time in prison much further from home, which makes visits from family and friends much less likely.

The existence of the federal criminal justice system raises two important questions for our analysis of immigration and state inmates. Are there native / foreign-born differences in the mix of inmates serving time on "federal-only" offenses? For those offenses with concurrent jurisdiction, does the margin for moving into the federal jurisdiction differ between the foreign born and natives? Because data comparable to our California sample do not exist, this section reviews data from several sources, all of which require approximations to the concept of nativity used elsewhere in this paper.

Table 3 reports information from the United States Sentencing Commission Monitoring database of all cases resulting in conviction in U.S. District Courts in 1994-95. ${ }^{14}$ This table shows that noncitizens were over represented among those from California convicted in U.S. Courts. Noncitizens were primarily convicted of immigration and drug violations. Furthermore, there are important differences between legal and illegal immigrants -- nearly 60 percent of the illegal immigrant males were convicted of immigration violations. However, excluding immigration offenses, drug violations were very important to each group, and comprise a larger proportion of the noncitizen immigrant offenders than of the citizens. Therefore, these high proportions of immigrant drug offenders may indicate that the foreign born are differentially "missing" from analyses of state prison populations. 
A report from the Bureau of Justice Statistics suggests that, for drug offenders, the margin for noncitizens to move into federal jurisdiction may have been lower than for citizens (Scalia 1996). Scalia notes that, "Noncitizens convicted of a Federal drug offense were more likely than citizens to have played a minor role in the drug conspiracy. Approximately $29 \%$ of noncitizens convicted of a drug offense received a downward sentencing adjustment for 'mitigating role,' compared with 14\% of U.S. citizens." (Scalia 1996, p.1) While these findings have implications for the costs of incarcerating the foreign born in the federal criminal justice system, the existence of this system also has implications for the interpretation of results for states. If we were able to cleanly connect the data for both prison systems, we would find that the California data underestimates the disproportionate representation of the foreign born among drug offenders and the longer time served by the foreign born (which we show below).

\section{Laws and Enforcement}

The information presented in Tables 1 and 2 makes clear that the fraction of inmates who were foreign born, and the fraction of the foreign born with an INS hold on record, increased for both men and women. To understand why this happened, it is worth distinguishing the factors that affect the criminal justice system in general from those that determine whether an immigrant is deportable.

During the past decade, several changes have taken place in criminal justice policy that, while not aimed at immigrants directly, may nonetheless have had a disproportionate impact on their incarceration. A plethora of acts under the heading of the "war on drugs" has increased enforcement and penalties for violations involving controlled substances. (See Forst 1995 and Tonry 1995.) Data from our earliest time period, 1986, show that immigrants were disproportionately incarcerated for drug-related activity. If one interprets that to mean that the foreign born were disproportionately involved in drug crimes, then, as enforcement increased with the "war on drugs," a disproportionate number of foreign born would be caught in the net. 
Furthermore, immigrants and others with low levels of income and education may have poor (or no) representation in court. Because of language and cultural barriers, the foreign born may be particularly less likely to aid adequately in their own defense. Further, with few exceptions, federal law prohibits agencies from using funds from the Legal Services Corporation to represent aliens. With the increasing numbers of aliens requiring legal services and the expense of providing representation (due to the remote location of many detention facilities and prisons), the availability of pro bono representation is scarce. ${ }^{15}$ Thus, aliens may be more likely to be convicted than the native born who commit similar crimes.

There are also changes in the enforcement environment that may have had a specific impact on the foreign born. Consider the "war on drugs" again. There is a trivial reason this may have disproportionately affected the foreign born: since drugs tend to come from abroad, the couriers are often foreign born. As enforcement against drug smugglers increased, it is likely that the proportion foreign-born who are apprehended, convicted, and incarcerated also increased. As discussed earlier, this connection is worth keeping in mind, since these individuals are not necessarily among the some one million immigrants admitted for legal permanent resident status each year, but rather they are among the some 25 million people admitted each year on student, business, and tourist visas. As the discussion of immigration and crime become intertwined, it is worth noting that not all the foreign born who are incarcerated were necessarily admitted under the United States family-based admission criteria for permanent residents.

There have also been changes in U.S. policies toward criminal immigrants. Since the United States stopped its open border policy in the 1870s, criminal activity has been a basis for both exclusion and deportation of those who, until that point, had been legal residents. ${ }^{16}$ Only those immigrants who have become naturalized citizens are immune to deportation. Although "crimes of moral turpitude" and a host of other criminal activities have always been grounds for deportation, deportation was pursued rather selectively. As our 1986 data reveal, the foreign born with INS hold orders in 1986 were 
disproportionately incarcerated for violent crimes, and officials took longer in placing INS holds on inmates' records compared to later years.

Congressional legislation during the 1980s took away some of the INS's discretion over deportation proceedings, enlarged the categories of criminal activity for which deportation was required, and increased the resources of enforcement agencies. ${ }^{17}$ The Immigration Reform and Control Act (IRCA) of 1986 required the INS to start deportation proceedings as soon as possible after the conviction of a noncitizen. The Anti-Drug Abuse Act of 1988 introduced the term "aggravated felon," and required deportation against all noncitizens convicted of aggravated felonies. As originally defined, an aggravated felony consisted of such crimes as murder, drug or firearms trafficking, and money laundering. However, the term was amended and broadened in 1990 and 1994. By 1996, with the Illegal Immigration Reform and Immigrant Responsibility Act, the term "aggravated felon" applied to crimes of theft or burglary, provided the court imposed a sentence of at least one year, ${ }^{18}$ a conviction for fraud or deceit is now an aggravated felony if the loss is $\$ 10,000$ (Brady and Kesselbrenner, 1997, p. 6). The Anti-Terrorism and Effective Death Penalty Act of 1996 contained some overlapping provisions. Specified grounds for deportation in this Act included several provisions: "conviction of an aggravated felony, conviction of a controlled substance offense, drug addiction or abuse (no conviction necessary), conviction of a firearm offense," and several other miscellaneous crimes (Brady and Kesselbrenner, 1997, p. 4).

Note that these convictions need not result in prison time in order for a defendant to be "deportable." A conviction for a qualified offense which resulted in a suspended sentence or a sentence of probation meets the grounds for deportation. In addition, aggravated felonies need not be committed within any given time period following immigration. Therefore, a legal resident with one conviction after 20 years in the country would qualify for deportation. (In contrast, only those moral turpitude crimes committed within five years after admission are "qualifying offenses.") In 1996, the criminal grounds for deportability 
became retroactive, so a legal resident who had committed one of these offenses in the past, even if it was not grounds for deportation at the time, is now subject to deportation. ${ }^{19}$

In addition to the changes in the definition of the grounds for deportation, Congress also appropriated more funds for enforcement. The Institutional Hearing Program (IHP) was established in response to the IRCA requirement to initiate deportation proceedings more quickly. ${ }^{20}$ The process is supposed to work as follows: corrections officials identify new prisoners as foreign born; INS agents screen these prisoners for deportability; if an inmate is deportable, a detainer is filed requiring the inmate to be released to INS custody upon release from prison; deportation hearings are scheduled. The hope was that most deportable inmates would complete the entire process during the term of incarceration, and deportation would occur at the inmate's prison release date. (In practice, however, many deportable inmates were not identified by this process. ${ }^{21}$ )

The increases in resources to the INS coupled with increasing managerial attention to criminal aliens have yielded large increases in the numbers removed from the United States. Only 30,464 aliens were deported for criminal and narcotics violations over the entire decade of the 1980s (U.S. Department of Justice 1993); in 1997 alone, 50,165 criminal aliens were removed (U.S. Department of Justice, 1997b.). Among the removed criminal aliens, 61 percent had been convicted of aggravated felonies and 43 percent had drug convictions (U.S. Department of Justice, 1997b.). Fewer than 15,000 of the criminal aliens were removed through the Institutional Hearing Program (e.g., directly from a correctional institution), evidence of incomplete implementation (U.S. Department of Justice, 1997c).

Negotiated arrangements for expediting the processing of criminal aliens continue to develop between local offices of the INS and state and local law enforcement agencies. A recent INS effort, the Law Enforcement Support Center has pilot programs for improving the identification of illegal aliens who commit crimes (McDonald 1997). Because law enforcement is organized locally, and because populations vary substantially, systems must be adapted to the practices of police departments, sheriffs' offices, and 
departments of corrections. ${ }^{22}$ While removal is generally not permitted before the sentence is served, 1996 legislation increased the discretion of the Attorney General to remove nonviolent offenders early (Legomsky 1997a, p. 730).

The Violent Crime Control and Law Enforcement Act of 1994 provided "reimbursement" to states for incarceration of undocumented alien inmates. This reimbursement gives state officials an incentive to notify the Federal authorities of suspected illegal immigrants. ${ }^{23}$ This Act also increased funding to the INS to proceed with deportation hearings against criminal aliens.

Although only some of these laws were in effect by the time individuals in our sample were convicted, they demonstrate the rapidly changing environment toward criminal aliens. During the intervening years between each of our data sets, new laws were passed to either broaden grounds for deportation of criminal aliens, or to increase funding to the INS to initiate deportation proceedings. We observe changes in our data that correspond to these changes in policy. The expansion in offenses requiring deportation is reflected in the extent to which less serious offenders increasingly have INS holds on record (i.e., comparing 1990 and 1996 to 1986) and in the upswing in the numbers of criminal aliens awaiting deportation. Additionally, our data are consistent with these procedures becoming more systematic over time. One measure of this is the speed with which the INS hold orders were filed.

There are also several reasons to believe that the foreign born may be treated differently within the criminal justice system. These differences in treatment may, among other things, increase the costs of incarcerating the foreign born. ${ }^{24}$ For example, in the 1992 decision United States v. Restrepo it was determined that noncitizens held in the (federal) Bureau of Prisons are not allowed to serve any portion of their sentence in minimum security facilities or halfway houses. While this decision may be warranted if immigrants pose a much greater escape or flight risk than do the citizens, it will materially increase the costs of incarcerating them. ${ }^{25}$ 
Additionally, there are reasons deportable noncitizens may serve longer sentences for the same crime than do citizens. In Rodriguez v United States (1993), the second circuit court, relying on the statutory language from the Immigration and Nationality Act, determined that while the INS must begin any deportation proceeding as quickly as possible, alien prisoners will be required to serve their complete terms before they may be deported. Thus, noncitizens may be required to serve more of their sentences than citizens. ${ }^{26}$ Deportable aliens will spend more time behind bars than citizens for two additional reasons. First, they must wait in detention until the INS authorities come to get them, so any administrative delay will protract their time served. Second, once the INS authorities collect them, they are transferred to INS detention centers awaiting final decisions on their deportation status and removal to their country of origin. $^{27}$

\section{Multivariate Analysis of Sentence Length and Time Served}

The previous section reviewed the case law and legislation which serve both to increase the number of deportable aliens and, potentially, to increase the time they serve on a given sentence relative to citizens and other aliens. In this section, we use data from the California Department of Corrections to analyze the effect of an INS hold order on time served for noncitizens relative to comparable inmates.

\section{A. The Effect of Deportation Holds on Sentence Length and Time Served}

In anticipation of our analysis of time actually served, we begin with an examination of the effect of INS status on sentence length because the sentence is a potentially important control for criminal activity. We control for six offense categories, race and ethnicity, and three categories of foreign-born. The policies outlined above should not increase a deportable immigrant's sentence length if we had perfect controls for the details of their crimes, their criminal history, and there were equal treatment under the law. We do not have access to information on the first two of these, and the last is in some doubt. 
We control for six broad offense categories: manslaughter, property, assault, sex, drug, and other offenses. Although additional offense categories are available in the data, ${ }^{28}$ offense severity is one dimension along which bias in the criminal justice system may be manifested. Under determinate sentencing, the conviction offense should map into the sentence. ${ }^{29}$ In practice, the conviction offense is reached through the discretion of the prosecutor and plea bargaining. Kessler and Piehl (1998) recommend "stepping back" from the crime of conviction to that of the original charge in order to get closer to the actual action that led to arrest. Since we do not have this earlier information, we use these broader offense categories to avoid over controlling for the sentence.

We include several other control variables. Since the foreign born tend to be members of racial and ethnic minorities, we control for black, Hispanic, and other race. We also include controls for age at admission and age at admission squared. Age may affect sentence length because the older an individual is, the more likely she or he will have a longer criminal history.

We also control for three categories of the foreign born: all foreign born, those foreign born with "INS holds," and the foreign born with "late holds." There are reasons to use each of these comparison groups. First, all foreign born in California are likely to have difficulty in English. To the extent that this hampers their ability to aid in their own defense, they may be more likely to be convicted or to receive longer sentences upon conviction. ${ }^{30}$ Secondly, the foreign born are likely to have had less time in the United States, and thus have shorter (domestic) official criminal records. The "late" INS holds are interesting because they may have unobservables similar to those of the INS-hold foreign born, since both are eventually deemed "deportable."

Table 4a presents the OLS regressions for sentence length for men in 1986 and 1990, for all offenses, drug offenses, and property offenses. The left-hand side variable is the natural log of sentence length. One would like to estimate the sentence length for all crime categories separately because there 
were changes in punishments associated with these crime categories over these years. However, we only have sufficient data to estimate the two largest crime categories separately.

Before turning to estimates for the groups of the foreign born, note the effects of race and ethnicity. African Americans had significantly shorter sentences, all else equal, overall and for property offenses. In 1990, blacks convicted of drug offenses had longer sentences than non-Hispanic whites. The indicator for Hispanic was negative and significant in all specifications. The "other race" indicator was insignificant in most cases.

The "INS hold" coefficient was large, positive, and significant across all specifications. The effect was larger in 1986 than in 1990. The coefficient implies that those with INS holds were serving 39.6 percent, 47.2 percent, and 45.3 percent longer sentences for all, drug, and property offenses, respectively, than are other "similar" individuals. By 1990, the analogous figures were 14.5 percent, 15.2 percent, and 8.3 percent for all, drug, and property offenses. This is consistent with the fact that the list of deportable crimes was expanding during this time period to include less and less serious crimes.

How should we interpret this coefficient on "INS hold"? If the offense categories control for all pertinent aspects of an individual's criminal activity, then none of the other variables should matter. Clearly, this is not the case. As discussed above, there are several things that are relevant for sentencing for which we have no information: details about the exact criminal act, and the individual's criminal history. To the extent that "foreign born" controls for criminal history, we want to control for it and assess the "INS hold" coefficient on its own. To the extent that "INS hold" merely indicates that these are the individuals who are committing more serious crimes, we may want to compare the "INS hold" to the "late hold" coefficient. These are both groups of people who turn out to be "deportable," and so may have similar underlying characteristics to their crimes. In this case, "INS hold" seems to add considerably to the sentence length since "INS hold" was positive and significant and "late hold" was negative and significant across all specifications. Of course, the fact that the "late hold" individuals were not determined to be 
deportable until after their release may indicate that they either had very short sentences and were in and out of the system before the INS could catch up with them, or that they committed lower priority crimes so no one immediately looked into their deportation status. If we want to compare the foreign born with INS holds to the native born, we need to add the "INS hold" coefficient to the coefficient on foreign born. INShold foreign born received three to 31 percent longer sentences than the native born, depending on the year and the specification.

Table $4 \mathrm{~b}$ reports the results for sentence length for women in 1990, overall and for drug offenses. There were not enough observations to run the 1986 specifications for women, and there were not enough late-hold foreigners to include that variable in these regressions. INS-hold foreigners receive about 30 to 35 percent longer sentences than other foreigners, and they received about 24 to 26 percent longer sentences than the native born. These effects were similar in direction to those for the men, but they were larger than the 1990 effects for men.

In sum, the foreign born with an INS hold on record received significantly longer sentences than other groups. We do not have a particular interpretation to give to these results. Rather, they inform the upcoming results of our analyses of time served. To the extent that this reflects differences in criminal history or differences in the severity of the crime, we want to control for sentence length when analyze actual time served. To the extent that the effect of "INS hold" reflects bias in the system against this group of noncitizens, we do not want to control for its effects when we analyze time served. We present both specifications in what follows.

Table 5a presents OLS regression results for the natural log of time served. All the controls we used in the sentence length regressions are included here. In the first regression for each pair, we add the $\log$ of sentence length and its square on the right-hand side. ${ }^{31}$ The specifications that include all offenses show that the foreign born with INS holds served significantly longer sentences (by about six percent) than did other similar inmates in both years. For drug offenses, the coefficient on "INS hold" was .038 
(insignificant) in 1986 and .058 in 1990. This figure was slightly larger for property offenses, with "INS hold" increasing time served approximately eight percent in 1986 and approximately 13 percent in 1990. Those foreign born with a "late hold" or no hold served less time (in most specifications). Compared to other inmates with similar characteristics and the same sentence length, the INS-hold foreign born served significantly more time. When we look within drug and property offenses, we see that this effect was larger in 1990 than in 1986. This suggests that the penalty for being deportable was increasing over time.

As described above, if we want to compare the INS-hold foreign born to the native born, we need to add the coefficients on "INS hold" and "foreign born." Whether or not this is the right exercise depends on whether the INS-hold foreign born are more similar to other foreign born or to natives in terms of the prior criminal history and behavior within the prison system. These data cannot answer this question, so it is worth noting that the differences in time served between the INS-hold foreign born and the native born were smaller than between the INS-hold foreign born and those foreign born without a hold order. However, except for the case of drug offenses in 1986, the INS-hold foreign born served significantly longer time than the native born, and the differential was between three and five percent.

If one believes that all effects of "INS hold" on sentence length in the previous tables were the result of differences in the severity of the criminal act, then controlling for sentence length in these specifications should account for this source of differences. The effect of INS holds on time served in these specifications can only result from differences in pre-confinement points, behavior in prison, or differences in treatment within the criminal justice system. Pre-confinement points come about if the individual is held during trial. This is more likely if someone is unable to make bail, or is more likely to have a trial. There is some evidence that noncitizens are less likely to be free on bail before trial (Hagan and Palloni 1997). The relationship between citizenship and plea-bargaining is more complicated. If noncitizens have poor legal representation, they may be more likely to accept a plea bargain. On the other hand, the current deportation consequences of a felony conviction may lead noncitizens to go to trial. In the latter case, the 
subsample of those convicted noncitizens will have longer average sentences (since they do not receive any discount from guilty pleas). Then, the inclusion of sentence length will tend to bias downward the coefficient on "INS hold."

We have no direct information on behavior in prison, but have no a priori reason to believe "INS hold" foreign born would have worse behavior than the other groups. The 1991 Survey of Inmates of State Prisons provides some handle on the question of behavior in prison, since it includes variables on "rulebreaking" while incarcerated. For this check, we were able to compare citizens to noncitizens, which is not exactly comparable to our California analyses. Due to the small sample sizes, we could not always look at the desired level of detail. (For example, the survey contained no female noncitizens in California prisons who had broken a major rule.) In the national sample (with state fixed effects) there was no difference in the extent of rule-breaking between citizen and noncitizen males when all offenders were considered together or among only drug offenders. Among women, citizens had statistically significantly higher rates of rule-breaking. For male California inmates only, again there was no difference in behavior. In none of the specifications we ran for rule-breaking was the coefficient on citizen negative. Thus, we do not believe that behavioral differences in prison explain the finding that those with INS holds serve a longer proportion of their sentences.

Another potential problem in the interpretation of the INS hold coefficient is reverse causality. Suppose that for some unknown reason (e.g., behavior in prison, pre-confinement credits) some individuals stay in prison longer for a given sentence length. The INS would then have longer to identify who was deportable and then file hold orders. Longer time served would, in effect, cause inmates to be deemed deportable. We do not think our results are driven by reverse causation. As mentioned earlier, in 1986 it may have been the case that deportation holds were filed selectively and the longer one was in prison, the greater the chance that officials would decide to investigate one's deportation status. But by 1990, the placement of INS holds had become much more systematic. Over three-quarters of all holds were placed 
within the first four months of detention. As a further check for possible reverse causation, we reran the regressions in Table 5a on the sample of individuals who were sentenced to at least two years in prison. We then limited the definition of INS hold to those whose hold was placed within three months of admission. Among this group, it cannot be the case that reverse causation drives our results, as reverse causation implies that those who stay in prison longer are more likely to be identified as deportable. This group serves a long sentence and the INS hold is filed almost immediately. Our results using this sample are very similar to the reported results in Table 5a. For example, inmates with INS holds served 11.2 percent longer in 1986 and 11.5 percent longer in 1990.

The final explanation for the positive relationship between "INS hold" and time served, that there are differences in treatment, is consistent with the idea that there are statutory reasons why these noncitizens must serve out their sentences prior to deportation, and that there might be some delay before the INS can transfer them to a deportation facility.

If one believes that the effects of "INS hold" on sentence length represents some sort of improper bias toward this group, then one would not want to control for it in the time served regressions. The second column in each year/offense group shows the results excluding the log of sentence length and its square. In this case, the effect of having an INS hold on one's record is enormous. INS-hold foreign born served between 50 and 60 percent longer sentences in 1986. This effect was much smaller in 1990, only about 23 percent. This is undoubtedly because the list of offenses that were considered grounds for deportation increased dramatically in these two time periods, so the foreign inmates with INS holds have shorter sentences on average in 1990, although there are more of them.

Table $5 \mathrm{~b}$ shows the results for time served for women. We could not perform identical analyses to those for the men because the sample sizes were too small. The results controlling for sentence length show that the foreign born with INS holds served about 12 percent more time when we consider all offenses together. Within drug offenses, there was a positive but insignificant effect. The race and ethnicity 
variables similarly have little effect here. Similar to the men, when sentence length is not included, the coefficient on "INS hold" was very large — this group serves about 45 percent longer.

\section{B. Recent Evidence on the Effect of Deportation Holds}

As described in section IV, policies toward criminal aliens have become increasingly severe. Although some of these policies took effect between 1986 and 1990, more were instituted between 1990 and 1996. It is worthwhile, then, to investigate more recent evidence.

While we have data from 1996, we only observe these inmates until June 30 of 1997. In order to observe a completed spell of incarceration, an inmate would have had to serve approximately one year. In order to analyze comparable samples across the years, for each year we include only those who were admitted during the first six months of a year and released by the end of June of the following calendar year. This new subsample shifts the offense distribution of inmates away from violent crimes and toward drug and property crimes. Nonetheless, there are a substantial number of men who serve approximately a year in prison. For women, however, the sample sizes are too small to analyze such short terms.

Table 6 shows the OLS estimates for the natural log of time served for this sample of men serving short prison terms and, in the last row, the marginal effects of "INS hold" for being included in this subsample. These regressions are analogous to those in Table 5b, although the log of sentence length and its square are always included. Once again, we show the estimates for all offense groups combined, and for drug and property offenses separately.

The point of this exercise is to investigate the magnitude of the "INS hold" coefficient over time. The extent to which these coefficients are comparable depends on whether the underlying distributions of inmates are similar over the decade. This is a problem generally in periods when incarceration policy and enforcement environments are changing, but may be a particular problem in these specifications since the sample is truncated to include only those with relatively short sentences. We will take up later the 
implications of the selection into this sample and whether these coefficients can be generalized to the broader prison population.

Looking across the columns of Table 6, we can see that the effect of "INS hold" on time served dramatically increases from 1986 to 1996 . In 1986, the foreign born with INS holds on record did not serve significantly different time from other inmates. By 1990, they served between seven and 14 percent longer. By 1996, the foreign born under INS hold orders served 20 to 25 percent longer than other similar inmates.

Do these striking changes across the years represent a real change in the treatment of foreign born inmates under INS hold orders, or do they result simply from a change in the underlying distribution of who is included in the short term sample? Consider the last row of the table. This reports the marginal effect of "INS hold" (estimated using a probit model) on being in this short term sample, controlling for the complete list of variables listed in the time served regression. For all offense groups combined and the subset of drug offenders, INS-hold foreign born were significantly less likely to be in this short term sample in 1986 and 1990. By 1996, the INS-hold inmates in these offense groups were no different from other inmates in terms of their probability of being in this sample. Thus there is some evidence that the selection into this sample has changed over time.

How important is this for the comparability of these estimates? It is difficult to sign the "selection bias" without a great deal of further information. ${ }^{32}$ However, note that the selection into the short term sample does not appear to have changed over time for the subset of inmates convicted of property offenses. An INS hold order has no significant relationship to the probability of being in the short term sample for any of the years for property offenders. Nonetheless, the coefficients on "INS hold" in the time-served regressions for property offenders show a very similar pattern to that in the other specifications: the impact increased steeply over time. 
There are reasons to believe that the magnitude of these impacts may not generalize to the rest of the population. Suppose the "INS hold" effect comes mainly from bureaucratic delay — it takes time for the INS to complete deportation hearings and to take charge of a deportable alien. The size of this delay will be proportionally larger for those who are serving shorter periods of time overall. However, comparing the size of the "INS hold" effect in Table 6 to that in Table 5a further supports our interpretation that something fundamental has changed in the treatment of inmates based on their INS hold status, and our sample selection is not driving these results. In the former table, we have the experience of the one-fourth to one-fifth of the population serving the shortest terms. The effect of having an "INS hold" in 1986 was insignificant for those serving short terms where it was positive in Table 5a. In 1990, however, there was little difference in the magnitude of the coefficients for "INS hold" between the short term and broader populations.

We were interested in whether the experience of Mexicans differed from that of other foreign-born inmates. In particular, it seemed likely that improvements in the processing of criminal aliens for deportation would be easiest to achieve for Mexican citizens, both because they comprise the largest number of foreign born in California prisons and due to the physical proximity of Mexico. Interestingly, we found no evidence that (1) those inmates with INS holds who were born in Mexico served a lower proportion of their sentence than other inmates with INS holds, or (2) that there was a reduction (over time) in the proportion of sentence served by Mexicans relative to other inmates (all with INS holds).

\section{Conclusion}

Noncitizens are at risk for deportation if they are convicted of criminal offenses. The character of that risk has changed substantially over the past decade due to (1) legislation broadening the list of offenses which "qualify" for deportation and making certain provisions retroactive, (2) court decisions clarifying the terms of confinement for inmates facing deportation, (3) increases in resources for enforcement against 
criminal aliens, (4) shifting emphasis of enforcement toward drug crimes, (5) reductions in the discretion allowed the INS in enforcing deportation provisions of the law, and (6) the introduction of financial incentives for states to identify noncitizens in their prison populations.

Our analysis of the inmates in California state prisons documents the current environment for criminal aliens and the extent of the recent changes in that environment. The legislative changes have had a large impact on California's prisoners. Fully 75 percent of male, and 33 percent of female, foreign-born inmates entering the system in 1996 had INS holds on their records. Those inmates with INS holds served longer in prison than similar native- or foreign-born inmates. The results also suggest that the differential in time served has been increasing over time, at least for inmates with relatively short sentences. It is possible that these differentials will narrow with time, if their cause is administrative delay and improvements are made.

Yet even if these differentials are temporary, they impose substantial costs. First, the inmates themselves bear the cost of serving longer terms behind bars. Without a full accounting of how time served in prison interacts with time spent in detention centers, it is difficult to place a value on this cost. While it is possible that inmates are better off serving longer sentences because options for appeal are limited after deportation, there is no evidence that this time can be utilized by inmates for their appeals. More generally, we are not aware of any studies of the impact of the recent developments in the treatment of criminal aliens on the deportation due process or on living conditions in deportation centers. Given the abrupt shifts in policy in a period of high immigration, it would not be surprising to find multiple bottlenecks in the process. If that is the case, the costs described in this paper severely understate the social costs of recent legislation regarding criminal aliens.

Second, for criminal justice as a whole, there is the question of the opportunity cost of resources. How would these cells be used if noncitizens served the same terms as citizens? It is possible that there would be no replacement of these inmates in the system. In that case, the current costs are borne by the 
inmates and guards operating in overly crowded conditions, which may or may not be a cause for concern. It is not hard to imagine, however, that the opportunity cost of these cells is additional offenders on probation who might otherwise be incarcerated.

Third, our results suggest that the direct costs of incarcerating immigrants are increasing because of the increase in absolute numbers and the differential time served by deportable aliens. How are those direct costs allocated across jurisdictions? Criminal aliens under deportation orders are released from prison and transported to INS deportation facilities. If the additional time in California prisons is used to adjudicate their deportation cases, then this extra time in state prisons may result in less time in INS deportation facilities, saving the federal government money. From the inmates' point of view, it may not matter where one resides except to the extent that being in one environment is preferable to another. However, from the state's point of view, it may matter a great deal. The longer individuals are in their prisons, the more it costs the state. While the federal government has begun to allocate funds to compensate states for criminal aliens, currently the reimbursement rate is much less than one.

The Violent Crime Control and Law Enforcement Act of 1994 provided "reimbursement" to states for incarceration of undocumented alien inmates. This reimbursement gives state officials an incentive to notify the Federal authorities of suspected illegal immigrants. In practice, the State Criminal Alien Assistance Program (SCAAP) partially reimburses states for expenses of incarcerating certain criminal aliens (convicted of one felony or two misdemeanors). In fiscal year 1996, the reimbursement rate was 60 cents for each dollar claimed (US Department of Justice, 1997a).

While 60 percent of these costs are being "reimbursed," it may not be sufficient to cover the costs associated the longer terms served. First, capital costs are not included in the reimbursable amounts (US Department of Justice 1997a). Second, the "extra" time served by deportable aliens is sufficient to overcome the benefits of SCAAP funds. Using the time served of the native born as a proxy for the "base cost" of incarceration in the absence of the INS deportation policy, the state loses money by identifying 
potentially deportable inmates when the multiplier on time served for deportable aliens is less than one over the reimbursement rate. Some of the estimates of the "time-served multiplier" in this paper suggest that even at a 60 percent reimbursement rate, California is close to the point of losing money by identifying deportable aliens. Further, the reimbursement rate is a function of the claims, since the appropriation for SCAAP is fixed. Therefore, if claims from states increase, the reimbursement rate could fall dramatically. So at the same time the federal government began to share in the cost of incarcerating alien inmates, it also passed additional laws governing the terms of incarceration which had substantial impacts on state governments. 


\section{References}

Borjas, George (1990), Friends or Strangers: The Impact of Immigration on the U.S. Economy, Basic Books.

Brady, Katherine and Dan Kesselbrenner (1997), "Recent Developments in the Immigration Consequences of Crimes," National Immigration Project Newsletter, Volume 23, Issue 4, February.

Butcher, Kristin F. and Anne Morrison Piehl (1998a), "Recent Immigrants: Unexpected Implications for Crime and Incarceration," Industrial and Labor Relations Review, Volume 51, No. 4, pp.654-679.

(1998b), "Cross-City Evidence on the Relationship Between Immigration and Crime," Journal of Policy Analysis and Management, Volume 17, No. 3, pp.457-493.

Carling, Duane D. (1994), "Recent Development: J. Rodriguez v. United States: Adjustments to the Length of Incarceration for Alien Convicts Expecting Deportation," Journal of Contemporary Law, pp.272-.

Clark, Rebecca L., Jeffrey S. Passel, Wendy Zimmerman, and Michael E. Fix (1994), Fiscal Impacts of Undocumented Aliens: Selected Estimates for Seven States, Urban Institute

Dilulio, John J., Jr., Steven K. Smith, and Aaron J. Singer (1995), “The Federal Role in Crime Control," in James Q. Wilson and Joan Petersilia, eds., Crime, San Francisco: ICS Press, pp. 445-462.

Forst, Brian (1995), "Prosecution and Sentencing," in James Q. Wilson and Joan Petersilia, eds., Crime, San Francisco: ICS Press, pp. 363-386.

General Accounting Office (1997), Criminal Aliens: INS' Efforts to Identify and Remove Imprisoned Aliens Need to be Improved (Testimony, 07/15/97, GAO/T-GGD-97-154).

Glaeser, Edward, Daniel Kessler, and Anne Morrison Piehl (1998), "What Do Prosecutors Maximize?" National Bureau of Economics working paper \#6602.

Grogger, Jeffrey T. (1998), "Immigration and Crime Among Young Black Men: Evidence from the National Longitudinal Survey of Youth," in Daniel S. Hamermesh and Frank D. Bean, eds., Help or Hindrance: The Economic Implications of Immigration for African Americans, New York: Russell Sage Foundation, pp. 322-341.

Hagan, John and Alberto Palloni (1997), "Sociological Criminology and the Myth of the Mexican Criminal," Unpublished paper, University of Toronto.

Kessler, Daniel P. and Anne Morrison Piehl (1998), "The Role of Discretion in the Criminal Justice System," Journal of Law, Economics and Organization, Volume 14, No. 2, pp. 256-276.

Legomsky, Stephen H. (1997a), Immigration and Refugee Law and Policy, Foundation Press, $2^{\text {nd }}$ edition. 
(1997b),"Non-Citizens and the Rule of Law: the 1996 Immigration Reforms," Research Perspectives on Migration, Volume 1, No. 4.

McDonald, William F. (1997), "Crime and Illegal Immigration: Emerging Local, State, \& Federal Partnerships,” National Institute of Justice Journal (June), U.S. Department of Justice, pp. 2-10.

McShane, Marilyn D. (1987), "Immigration Processing and the Alien Inmate: Constructing a Conflict Perspective," Journal of Crime \& Justice, Volume 10, No. 1, pp. 171-194.

Sampson, Robert J. and Janet L. Lauritsen (1997), "Racial and Ethnic Disparities in Crime and Criminal Justice in the United States," in Michael Tonry, ed., Crime and Justice: A Review of Research (Ethnicity, Crime and Immigration), Chicago: University of Chicago Press.

Scalia, John (1996), "Noncitizens in the Federal Criminal Justice System, 1984-94," U.S. Department of Justice, August.

Smith, James P. and Barry Edmonston, eds. (1997), The New Americans: Economic, Demographic, and Fiscal Effects of Immigration, Washington DC: National Academy Press.

Tonry, Michael (1995), Malign Neglect, Oxford: Oxford University Press.

U.S. Department of Justice (1997a), State Criminal Alien Assistance Program, Bureau of Justice Assistance Fact Sheet, Washington DC, June.

(1997b), "INS Increases Removals a Record 62 Percent Over FY 1996," Immigration and Naturalization Service News Release, October 30, 1997.

(http://www.ins.usdoj.gov/public_affairs/press_releases/fyremov.html).

(1997c), "The Year in Review: Highlights of 1997," Immigration and Naturalization Service News Release, (undated). (http://www.ins.usdoj.gov/public_affairs/press_releases/yearin.html).

U.S. Department of Justice (1993), Statistical Yearbook of the Immigration and Naturalization Service : 1993, Washington DC.

United States Budget, Appendix, Fiscal Year 1986, p. I-N16.

United States Budget, Appendix, Fiscal Year 1996, p. 684. 
Table 1a: Descriptive Statistics for Men in Admissions Cohorts (standard errors)

\begin{tabular}{|c|c|c|c|c|c|c|}
\hline & \multicolumn{2}{|c|}{1986} & \multicolumn{2}{|c|}{1990} & \multicolumn{2}{|c|}{1996} \\
\hline \multirow[t]{2}{*}{$\begin{array}{l}\text { Fraction } \\
\text { Foreign-born }\end{array}$} & \multicolumn{2}{|c|}{$\begin{array}{c}0.1892 \\
(0.0027)\end{array}$} & \multicolumn{2}{|c|}{$\begin{array}{c}0.2473 \\
(0.0023)\end{array}$} & \multicolumn{2}{|c|}{$\begin{array}{c}0.2745 \\
(0.0023)\end{array}$} \\
\hline & $\begin{array}{c}\text { Native- } \\
\text { born }\end{array}$ & $\begin{array}{l}\text { Foreign- } \\
\text { born }\end{array}$ & $\begin{array}{c}\text { Native- } \\
\text { born }\end{array}$ & $\begin{array}{c}\text { Foreign- } \\
\text { born }\end{array}$ & $\begin{array}{c}\text { Native- } \\
\text { born }\end{array}$ & $\begin{array}{c}\text { Foreign- } \\
\text { born }\end{array}$ \\
\hline Age at Admission & $\begin{array}{c}29.49 \\
(0.067)\end{array}$ & $\begin{array}{l}28.49^{*} \\
(0.131)\end{array}$ & $\begin{array}{c}30.65 \\
(0.056)\end{array}$ & $\begin{array}{l}28.77 * \\
(0.088)\end{array}$ & $\begin{array}{c}32.13 \\
(0.056)\end{array}$ & $\begin{array}{l}30.24 * \\
(0.082)\end{array}$ \\
\hline White & $\begin{array}{c}0.3688 \\
(0.0037)\end{array}$ & $\begin{array}{c}0.0945^{*} \\
(0.0046)\end{array}$ & $\begin{array}{c}0.3706 \\
(0.0030)\end{array}$ & $\begin{array}{c}0.0488^{*} \\
(0.0023)\end{array}$ & $\begin{array}{c}0.3952 \\
(0.0029)\end{array}$ & $\begin{array}{c}0.0405^{*} \\
(0.0019)\end{array}$ \\
\hline Black & $\begin{array}{c}0.3912 \\
(0.0037)\end{array}$ & $\begin{array}{l}0.0459 * \\
(0.0033)\end{array}$ & $\begin{array}{c}0.3838 \\
(0.0030)\end{array}$ & $\begin{array}{l}0.0290 * \\
(0.0018)\end{array}$ & $\begin{array}{c}0.3201 \\
(0.0028)\end{array}$ & $\begin{array}{l}0.0175 * \\
(0.0013)\end{array}$ \\
\hline Hispanic & $\begin{array}{c}0.2170 \\
(0.0032)\end{array}$ & $\begin{array}{c}0.7214^{*} \\
(0.0071)\end{array}$ & $\begin{array}{c}0.2249 \\
(0.0026)\end{array}$ & $\begin{array}{c}0.8473^{*} \\
(0.0039)\end{array}$ & $\begin{array}{c}0.2596 \\
(0.0026)\end{array}$ & $\begin{array}{l}0.8680 * \\
(0.0033)\end{array}$ \\
\hline Mexican & $\begin{array}{c}0.2010 \\
(0.0031)\end{array}$ & $\begin{array}{c}0.6946^{*} \\
(0.0073)\end{array}$ & $\begin{array}{c}0.1943 \\
(0.0025)\end{array}$ & $\begin{array}{l}0.7622 * \\
(0.0046)\end{array}$ & $\begin{array}{c}0.1845 \\
(0.0023)\end{array}$ & $\begin{array}{l}0.7472 * \\
(0.0042)\end{array}$ \\
\hline $\begin{array}{l}\text { Sentence Length } \\
\text { [Median] }\end{array}$ & $\begin{array}{c}47.14 \\
(0.436) \\
{[36]}\end{array}$ & $\begin{array}{c}42.93 * \\
(0.669) \\
{[36]}\end{array}$ & $\begin{array}{c}41.12 \\
(0.318) \\
{[24]}\end{array}$ & $\begin{array}{c}39.70 * \\
(0.380) \\
{[32]}\end{array}$ & $\begin{array}{c}45.19 \\
(0.407) \\
{[32]}\end{array}$ & $\begin{array}{c}45.37 \\
(0.777) \\
{[36]}\end{array}$ \\
\hline Property Offense & $\begin{array}{c}0.3901 \\
(0.0037)\end{array}$ & $\begin{array}{l}0.3004 * \\
(0.0073)\end{array}$ & $\begin{array}{c}0.3028 \\
(0.0029)\end{array}$ & $\begin{array}{l}0.2041 * \\
(0.0044)\end{array}$ & $\begin{array}{c}0.2860 \\
(0.0027)\end{array}$ & $\begin{array}{l}0.1797 * \\
(0.0037)\end{array}$ \\
\hline Assault Offense & $\begin{array}{c}0.2639 \\
(0.0034)\end{array}$ & $\begin{array}{l}0.2260 * \\
(0.0066)\end{array}$ & $\begin{array}{c}0.2095 \\
(0.0025)\end{array}$ & $\begin{array}{l}0.1587 * \\
(0.0040)\end{array}$ & $\begin{array}{c}0.2227 \\
(0.0025)\end{array}$ & $\begin{array}{l}0.1792 * \\
(0.0037)\end{array}$ \\
\hline Drug Offense & $\begin{array}{c}0.2046 \\
(0.0031)\end{array}$ & $\begin{array}{c}0.3315^{*} \\
(0.0075)\end{array}$ & $\begin{array}{c}0.3010 \\
(0.0029)\end{array}$ & $\begin{array}{l}0.4528^{*} \\
(0.0054)\end{array}$ & $\begin{array}{c}0.3249 \\
(0.0028)\end{array}$ & $\begin{array}{c}0.4583^{*} \\
(0.0048)\end{array}$ \\
\hline Drug Possession & $\begin{array}{c}0.0726 \\
(0.0020)\end{array}$ & $\begin{array}{c}0.0639 \\
(0.0039)\end{array}$ & $\begin{array}{c}0.1117 \\
(0.0020)\end{array}$ & $\begin{array}{c}0.0944 * \\
(0.0032)\end{array}$ & $\begin{array}{c}0.1512 \\
(0.0021)\end{array}$ & $\begin{array}{c}0.0990^{*} \\
(0.0029)\end{array}$ \\
\hline $\begin{array}{l}\text { Man- } \\
\text { slaughter }\end{array}$ & $\begin{array}{c}0.0413 \\
(0.0015)\end{array}$ & $\begin{array}{c}0.0524 * \\
(0.0036)\end{array}$ & $\begin{array}{c}0.0277 \\
(0.0010)\end{array}$ & $\begin{array}{c}0.0360^{*} \\
(0.0020)\end{array}$ & $\begin{array}{c}0.0246 \\
(0.0009)\end{array}$ & $\begin{array}{c}0.0284 * \\
(0.0016)\end{array}$ \\
\hline Sex Offense & $\begin{array}{c}0.0633 \\
(0.0019)\end{array}$ & $\begin{array}{c}0.0546^{*} \\
(0.0036)\end{array}$ & $\begin{array}{c}0.0435 \\
(0.0013)\end{array}$ & $\begin{array}{c}0.0408 \\
(0.0021)\end{array}$ & $\begin{array}{c}0.0424 \\
(0.0012)\end{array}$ & $\begin{array}{c}0.0469 \\
(0.0020)\end{array}$ \\
\hline INS hold & 0 & $\begin{array}{l}0.3054 * \\
(0.0073)\end{array}$ & 0 & $\begin{array}{l}0.6832 * \\
(0.0051)\end{array}$ & 0 & $\begin{array}{l}0.7495 * \\
(0.0042)\end{array}$ \\
\hline Sample Size & 17,100 & 3,991 & 25,821 & 8,482 & 28,450 & 10,763 \\
\hline
\end{tabular}

Notes: Authors' calculations from California Department of Corrections data. See text for description of the data and sample restrictions. Mexican is a subset of Hispanic. Drug possession is a subset of the drug offense category. "Other" offenses are omitted. An asterisk indicates the mean is different from the mean in the previous column at the 5 percent level of statistical significance. 
Table 1b: Descriptive Statistics for Women in Admissions Cohorts (standard errors)

\begin{tabular}{|c|c|c|c|c|c|c|}
\hline \multirow{4}{*}{$\begin{array}{l}\text { Fraction } \\
\text { Foreign-born }\end{array}$} & \multicolumn{2}{|c|}{1986} & \multicolumn{2}{|c|}{1990} & \multicolumn{2}{|c|}{1996} \\
\hline & \multirow{2}{*}{\multicolumn{2}{|c|}{$\begin{array}{c}0.0718 \\
(0.0060)\end{array}$}} & \multirow{2}{*}{\multicolumn{2}{|c|}{$\begin{array}{c}0.0732 \\
(0.0044) \\
\end{array}$}} & \multirow{2}{*}{\multicolumn{2}{|c|}{$\begin{array}{c}0.0958 \\
(0.0043) \\
\end{array}$}} \\
\hline & & & & & & \\
\hline & $\begin{array}{c}\text { Native- } \\
\text { born }\end{array}$ & $\begin{array}{c}\text { Foreign- } \\
\text { born }\end{array}$ & $\begin{array}{c}\text { Native- } \\
\text { born }\end{array}$ & $\begin{array}{l}\text { Foreign- } \\
\text { born }\end{array}$ & $\begin{array}{c}\text { Native- } \\
\text { born }\end{array}$ & $\begin{array}{l}\text { Foreign- } \\
\text { born }\end{array}$ \\
\hline Age at Admission & $\begin{array}{c}30.98 \\
(0.185)\end{array}$ & $\begin{array}{c}31.49 \\
(0.725)\end{array}$ & $\begin{array}{c}31.83 \\
(0.136)\end{array}$ & $\begin{array}{c}32.69 \\
(0.524)\end{array}$ & $\begin{array}{c}34.13 \\
(0.118)\end{array}$ & $\begin{array}{c}33.55 \\
(0.390)\end{array}$ \\
\hline White & $\begin{array}{c}0.3968 \\
(0.0118)\end{array}$ & $\begin{array}{l}0.2180^{*} \\
(0.0359)\end{array}$ & $\begin{array}{c}0.3807 \\
(0.0086)\end{array}$ & $\begin{array}{l}0.1732 * \\
(0.0238)\end{array}$ & $\begin{array}{c}0.4111 \\
(0.0075)\end{array}$ & $\begin{array}{l}0.1179 * \\
(0.0151)\end{array}$ \\
\hline Black & $\begin{array}{c}0.2986 \\
(0.0110)\end{array}$ & $\begin{array}{l}0.0677^{*} \\
(0.0219)\end{array}$ & $\begin{array}{c}0.3857 \\
(0.0086)\end{array}$ & $\begin{array}{l}0.0787 * \\
(0.0169)\end{array}$ & $\begin{array}{c}0.3387 \\
(0.0072)\end{array}$ & $\begin{array}{l}0.0437 * \\
(0.0096)\end{array}$ \\
\hline Hispanic & $\begin{array}{c}0.2526 \\
(0.0105)\end{array}$ & $\begin{array}{l}0.5113 * \\
(0.0435)\end{array}$ & $\begin{array}{c}0.1981 \\
(0.0070)\end{array}$ & $\begin{array}{l}0.5787^{*} \\
(0.0310)\end{array}$ & $\begin{array}{c}0.1947 \\
(0.0060)\end{array}$ & $\begin{array}{l}0.6638 * \\
(0.0221)\end{array}$ \\
\hline Mexican & $\begin{array}{c}0.2363 \\
(0.0103)\end{array}$ & $\begin{array}{l}0.4962 * \\
(0.0435)\end{array}$ & $\begin{array}{c}0.1757 \\
(0.0067)\end{array}$ & $\begin{array}{l}0.5079 * \\
(0.0314)\end{array}$ & $\begin{array}{c}0.1022 \\
(0.0046)\end{array}$ & $\begin{array}{l}0.5218 * \\
(0.0234)\end{array}$ \\
\hline $\begin{array}{l}\text { Sentence Length } \\
\text { [Median] }\end{array}$ & $\begin{array}{c}32.75 \\
(0.577) \\
{[24]}\end{array}$ & $\begin{array}{c}30.74 \\
(1.222) \\
{[24]}\end{array}$ & $\begin{array}{c}29.33 \\
(0.323) \\
{[24]}\end{array}$ & $\begin{array}{c}33.78 * \\
(1.596) \\
{[24]}\end{array}$ & $\begin{array}{c}30.54 \\
(0.377) \\
{[24]}\end{array}$ & $\begin{array}{c}37.70 * \\
(1.574) \\
{[32]}\end{array}$ \\
\hline Property Offense & $\begin{array}{c}0.4866 \\
(0.0121)\end{array}$ & $\begin{array}{l}0.3459 * \\
(0.0414)\end{array}$ & $\begin{array}{c}0.3543 \\
(0.0084)\end{array}$ & $\begin{array}{c}0.3307 \\
(0.0296)\end{array}$ & $\begin{array}{c}0.3621 \\
(0.0073)\end{array}$ & $\begin{array}{l}0.2336^{*} \\
(0.0198)\end{array}$ \\
\hline Assault Offense & $\begin{array}{c}0.1409 \\
(0.0084)\end{array}$ & $\begin{array}{c}0.1053 \\
(0.0267)\end{array}$ & $\begin{array}{c}0.0964 \\
(0.0052)\end{array}$ & $\begin{array}{c}0.0827 \\
(0.0173)\end{array}$ & $\begin{array}{c}0.1158 \\
(0.0049)\end{array}$ & $\begin{array}{c}0.1179 \\
(0.0151)\end{array}$ \\
\hline Drug Offense & $\begin{array}{c}0.2724 \\
(0.0107)\end{array}$ & $\begin{array}{l}0.4812 * \\
(0.0435)\end{array}$ & $\begin{array}{c}0.4747 \\
(0.0088)\end{array}$ & $\begin{array}{c}0.5157 \\
(0.0314)\end{array}$ & $\begin{array}{c}0.4560 \\
(0.0076)\end{array}$ & $\begin{array}{l}0.5721 * \\
(0.0231)\end{array}$ \\
\hline Drug Possession & $\begin{array}{c}0.1234 \\
(0.0079)\end{array}$ & $\begin{array}{c}0.1203 \\
(0.0283)\end{array}$ & $\begin{array}{c}0.2308 \\
(0.0074)\end{array}$ & $\begin{array}{c}0.1299 \\
(0.0211)\end{array}$ & $\begin{array}{c}0.2594 \\
(0.0067)\end{array}$ & $\begin{array}{c}0.1507^{*} \\
(0.0167)\end{array}$ \\
\hline $\begin{array}{l}\text { Man- } \\
\text { slaughter }\end{array}$ & $\begin{array}{c}0.0471 \\
(0.0051)\end{array}$ & $\begin{array}{c}0.0301 \\
(0.0149)\end{array}$ & $\begin{array}{c}0.0258 \\
(0.0028)\end{array}$ & $\begin{array}{c}0.0276 \\
(0.0103)\end{array}$ & $\begin{array}{c}0.0146 \\
(0.0018)\end{array}$ & $\begin{array}{c}0.0262 \\
(0.0075)\end{array}$ \\
\hline Sex Offense & $\begin{array}{c}0.0128 \\
(0.0027)\end{array}$ & $0^{*}$ & $\begin{array}{c}0.0044 \\
(0.0012)\end{array}$ & $0^{*}$ & $\begin{array}{c}0.0032 \\
(0.0009)\end{array}$ & $\begin{array}{c}0.0022 \\
(0.0022)\end{array}$ \\
\hline INS hold & 0 & $\begin{array}{l}0.1805^{*} \\
(0.0335)\end{array}$ & 0 & $\begin{array}{l}0.5827 * \\
(0.0310)\end{array}$ & 0 & $\begin{array}{c}0.3319 * \\
(0.0310)\end{array}$ \\
\hline Sample Size & 1,718 & 133 & 3,215 & 254 & 4,325 & 458 \\
\hline
\end{tabular}

Notes: See previous table. 
Table 2a: Descriptive Statistics for Men Released within Six Years of Admission by Admission Year

(standard errors)

\begin{tabular}{|c|c|c|c|c|c|c|c|c|}
\hline \multirow[b]{4}{*}{$\begin{array}{l}\text { Fraction of } \\
\text { Sample }\end{array}$} & \multicolumn{4}{|c|}{1986} & \multicolumn{4}{|c|}{1990} \\
\hline & \multirow[t]{2}{*}{$\underline{\text { Native }}$} & \multicolumn{3}{|c|}{$\underline{\text { Foreign born }}$} & \multirow[t]{2}{*}{$\underline{\text { Native }}$} & \multicolumn{3}{|c|}{$\underline{\text { Foreign born }}$} \\
\hline & & No hold & INS hold & $\begin{array}{l}\text { Late } \\
\text { hold }\end{array}$ & & No hold & INS hold & $\begin{array}{l}\text { Late } \\
\text { Hold }\end{array}$ \\
\hline & 0.810 & 0.101 & 0.056 & 0.034 & 0.752 & 0.065 & 0.169 & 0.014 \\
\hline $\begin{array}{l}\text { Sentence } \\
\text { Length } \\
\text { [Median] }\end{array}$ & $\begin{array}{c}40.10 \\
(0.204) \\
{[36]}\end{array}$ & $\begin{array}{c}32.97 \\
(0.461) \\
{[24]}\end{array}$ & $\begin{array}{c}53.96 \\
(0.826) \\
{[48]}\end{array}$ & $\begin{array}{c}27.05 \\
(0.565) \\
{[24]}\end{array}$ & $\begin{array}{c}36.20 \\
(0.167) \\
{[24]}\end{array}$ & $\begin{array}{c}33.26 \\
(0.504) \\
{[24]}\end{array}$ & $\begin{array}{c}38.66 \\
(0.327) \\
{[36]}\end{array}$ & $\begin{array}{c}27.81 \\
(0.652) \\
{[24]}\end{array}$ \\
\hline $\begin{array}{l}\text { Time Served } \\
\text { [Median] }\end{array}$ & $\begin{array}{c}18.01 \\
(0.103) \\
{[13.63]}\end{array}$ & $\begin{array}{c}13.96 \\
(0.218) \\
{[11.33]}\end{array}$ & $\begin{array}{c}25.32 \\
(0.405) \\
{[22.41]}\end{array}$ & $\begin{array}{c}11.41 \\
(0.290) \\
{[10.35]}\end{array}$ & $\begin{array}{c}15.94 \\
(0.078) \\
{[11.76]}\end{array}$ & $\begin{array}{c}14.20 \\
(0.242) \\
{[10.81]}\end{array}$ & $\begin{array}{c}17.37 \\
(0.162) \\
{[13.88]}\end{array}$ & $\begin{array}{c}11.59 \\
(0.351) \\
{[9.95]}\end{array}$ \\
\hline $\begin{array}{l}\text { Property } \\
\text { Offense }\end{array}$ & $\begin{array}{c}0.402 \\
(0.004)\end{array}$ & $\begin{array}{c}0.326 \\
(0.010)\end{array}$ & $\begin{array}{c}0.212 \\
(0.012)\end{array}$ & $\begin{array}{c}0.409 \\
(0.019)\end{array}$ & $\begin{array}{c}0.308 \\
(0.003)\end{array}$ & $\begin{array}{c}0.218 \\
(0.009)\end{array}$ & $\begin{array}{c}0.193 \\
(0.005)\end{array}$ & $\begin{array}{c}0.332 \\
(0.022)\end{array}$ \\
\hline $\begin{array}{l}\text { Assault } \\
\text { Offense }\end{array}$ & $\begin{array}{c}0.258 \\
(0.003)\end{array}$ & $\begin{array}{c}0.211 \\
(0.009)\end{array}$ & $\begin{array}{c}0.281 \\
(0.013)\end{array}$ & $\begin{array}{c}0.162 \\
(0.014)\end{array}$ & $\begin{array}{c}0.204 \\
(0.003)\end{array}$ & $\begin{array}{c}0.166 \\
(0.008)\end{array}$ & $\begin{array}{c}0.152 \\
(0.005)\end{array}$ & $\begin{array}{c}0.180 \\
(0.018)\end{array}$ \\
\hline $\begin{array}{l}\text { Drug } \\
\text { Offense }\end{array}$ & $\begin{array}{c}0.212 \\
(0.003)\end{array}$ & $\begin{array}{c}0.336 \\
(0.010)\end{array}$ & $\begin{array}{c}0.320 \\
(0.014)\end{array}$ & $\begin{array}{c}0.389 \\
(0.019)\end{array}$ & $\begin{array}{c}0.308 \\
(0.003)\end{array}$ & $\begin{array}{c}0.271 \\
(0.010)\end{array}$ & $\begin{array}{c}0.537 \\
(0.007)\end{array}$ & $\begin{array}{c}0.362 \\
(0.022)\end{array}$ \\
\hline $\begin{array}{l}\text { Drug } \\
\text { Possession }\end{array}$ & $\begin{array}{c}0.075 \\
(0.002)\end{array}$ & $\begin{array}{c}0.071 \\
(0.006)\end{array}$ & $\begin{array}{c}0.039 \\
(0.006)\end{array}$ & $\begin{array}{c}0.092 \\
(0.011)\end{array}$ & $\begin{array}{c}0.114 \\
(0.002)\end{array}$ & $\begin{array}{c}0.079 \\
(0.006)\end{array}$ & $\begin{array}{c}0.100 \\
(0.004)\end{array}$ & $\begin{array}{c}0.131 \\
(0.016)\end{array}$ \\
\hline $\begin{array}{l}\text { Man- } \\
\text { slaughter }\end{array}$ & $\begin{array}{c}0.034 \\
(0.001)\end{array}$ & $\begin{array}{c}0.033 \\
(0.004)\end{array}$ & $\begin{array}{c}0.081 \\
(0.008)\end{array}$ & $\begin{array}{c}0.013 \\
(0.004)\end{array}$ & $\begin{array}{c}0.023 \\
(0.001)\end{array}$ & $\begin{array}{c}0.034 \\
(0.004)\end{array}$ & $\begin{array}{c}0.031 \\
(0.002)\end{array}$ & $\begin{array}{c}0.017 \\
(0.006)\end{array}$ \\
\hline Sex Offense & $\begin{array}{c}0.056 \\
(0.002)\end{array}$ & $\begin{array}{c}0.042 \\
(0.004)\end{array}$ & $\begin{array}{c}0.088 \\
(0.008)\end{array}$ & $\begin{array}{c}0.009 \\
(0.004)\end{array}$ & $\begin{array}{c}0.039 \\
(0.001)\end{array}$ & $\begin{array}{c}0.054 \\
(0.005)\end{array}$ & $\begin{array}{c}0.034 \\
(0.002)\end{array}$ & $\begin{array}{c}0.008 \\
(0.004)\end{array}$ \\
\hline Sample Size & 16,483 & 2,052 & 1,142 & 684 & 25,200 & 2,173 & 5,662 & 473 \\
\hline
\end{tabular}

Notes: Authors' calculations from California Department of Corrections data. See text for description of the data and sample restrictions. Drug possession is a subset of the drug offense category. "Other" offenses are omitted. An asterisk indicates the mean is different from the mean in the previous column at the 5 percent level of statistical significance. 
Table 2b: Descriptive Statistics for Women Released within Six Years of Admission by Admission Year

(standard errors)

\begin{tabular}{|c|c|c|c|c|c|c|c|c|}
\hline \multirow[b]{4}{*}{$\begin{array}{l}\text { Fraction of } \\
\text { Sample }\end{array}$} & \multicolumn{4}{|c|}{1986} & \multicolumn{4}{|c|}{1990} \\
\hline & \multirow[t]{2}{*}{$\underline{\text { Native }}$} & \multicolumn{3}{|c|}{ Foreign born } & \multirow[t]{2}{*}{$\underline{\text { Native }}$} & \multicolumn{3}{|c|}{ Foreign born } \\
\hline & & No hold & INS hold & $\begin{array}{l}\text { Late } \\
\text { hold }\end{array}$ & & No hold & INS hold & $\begin{array}{l}\text { Late } \\
\text { hold }\end{array}$ \\
\hline & 0.928 & 0.054 & 0.013 & 0.005 & 0.927 & 0.028 & 0.043 & 0.003 \\
\hline $\begin{array}{l}\text { Sentence } \\
\text { Length } \\
\text { [Median] }\end{array}$ & $\begin{array}{c}31.50 \\
(0.461) \\
{[24]}\end{array}$ & $\begin{array}{c}27.56 \\
(1.230) \\
{[24]}\end{array}$ & & & $\begin{array}{c}28.95 \\
(0.298) \\
{[24]}\end{array}$ & $\begin{array}{c}26.60 \\
(1.440) \\
{[24]}\end{array}$ & $\begin{array}{c}38.20 \\
(2.167) \\
{[24]}\end{array}$ & \\
\hline $\begin{array}{l}\text { Time Served } \\
\text { [Median] }\end{array}$ & $\begin{array}{c}13.79 \\
(0.235) \\
{[11.10]}\end{array}$ & $\begin{array}{c}10.941 \\
(0.606) \\
{[9.94]}\end{array}$ & & & $\begin{array}{c}12.06 \\
(0.150) \\
{[9.94]}\end{array}$ & $\begin{array}{c}10.881 \\
(0.804) \\
{[8.38]}\end{array}$ & $\begin{array}{l}15.840 \\
(1.002) \\
{[11.63]}\end{array}$ & \\
\hline $\begin{array}{l}\text { Property } \\
\text { Offense }\end{array}$ & $\begin{array}{c}0.491 \\
(0.012)\end{array}$ & $\begin{array}{c}0.354 \\
(0.048)\end{array}$ & & & $\begin{array}{c}0.355 \\
(0.008)\end{array}$ & $\begin{array}{c}0.402 \\
(0.050)\end{array}$ & $\begin{array}{c}0.259 \\
(0.036)\end{array}$ & \\
\hline $\begin{array}{l}\text { Assault } \\
\text { Offense }\end{array}$ & $\begin{array}{c}0.142 \\
(0.008)\end{array}$ & $\begin{array}{c}0.121 \\
(0.033)\end{array}$ & & & $\begin{array}{c}0.096 \\
(0.005)\end{array}$ & $\begin{array}{c}0.082 \\
(0.028)\end{array}$ & $\begin{array}{c}0.088 \\
(0.023)\end{array}$ & \\
\hline $\begin{array}{l}\text { Drug } \\
\text { Offense }\end{array}$ & $\begin{array}{c}0.274 \\
(0.011)\end{array}$ & $\begin{array}{c}0.475 \\
(0.050)\end{array}$ & & & $\begin{array}{c}0.476 \\
(0.009)\end{array}$ & $\begin{array}{c}0.392 \\
(0.050)\end{array}$ & $\begin{array}{c}0.612 \\
(0.040)\end{array}$ & \\
\hline $\begin{array}{l}\text { Drug } \\
\text { Possession }\end{array}$ & $\begin{array}{c}0.124 \\
(0.008)\end{array}$ & $\begin{array}{c}0.141 \\
(0.035)\end{array}$ & & & $\begin{array}{c}0.232 \\
(0.007)\end{array}$ & $\begin{array}{c}0.155 \\
(0.037)\end{array}$ & $\begin{array}{c}0.109 \\
(0.026)\end{array}$ & \\
\hline $\begin{array}{l}\text { Man- } \\
\text { slaughter }\end{array}$ & $\begin{array}{c}0.041 \\
(0.005)\end{array}$ & $\begin{array}{c}0.010 \\
(0.010)\end{array}$ & & & $\begin{array}{c}0.025 \\
(0.003)\end{array}$ & $\begin{array}{c}0.021 \\
(0.015)\end{array}$ & $\begin{array}{c}0.034 \\
(0.015)\end{array}$ & \\
\hline Sex Offense & $\begin{array}{c}0.012 \\
(0.003)\end{array}$ & 0 & & & $\begin{array}{c}0.004 \\
(0.001)\end{array}$ & 0 & 0 & \\
\hline Sample Size & 1,703 & 99 & 24 & 10 & 3,204 & 97 & 147 & 9 \\
\hline
\end{tabular}

Notes: See previous table. 
Table 3. Offense Distribution: Convictions in U.S. District Courts 1994

\begin{tabular}{|c|c|c|c|c|c|c|}
\hline & & $\underline{\text { Men }}$ & & & $\underline{\text { Women }}$ & \\
\hline & Citizens & $\begin{array}{c}\text { Legal } \\
\text { Residents }\end{array}$ & $\begin{array}{c}\text { Illegal } \\
\text { Immigrants }\end{array}$ & Citizens & $\begin{array}{c}\text { Legal } \\
\text { Residents }\end{array}$ & $\begin{array}{c}\text { Illegal } \\
\text { Immigrants }\end{array}$ \\
\hline $\begin{array}{l}\text { Assault/ } \\
\text { Murder }\end{array}$ & .028 & .003 & .007 & .010 & .002 & 0 \\
\hline Bank Robbery & .061 & .013 & .002 & .019 & .002 & 0 \\
\hline $\begin{array}{l}\text { Larceny/ } \\
\text { Fraud }\end{array}$ & .243 & .163 & .066 & .424 & .208 & .113 \\
\hline $\begin{array}{l}\text { Racketeering } \\
\text { /Extortion }\end{array}$ & .090 & .060 & .020 & .152 & .122 & .074 \\
\hline Drug Offenses & .401 & .610 & .285 & .308 & .493 & .385 \\
\hline Immigration & .005 & .081 & .586 & .008 & .100 & .377 \\
\hline Firearms & .097 & .026 & .016 & .020 & .010 & .004 \\
\hline $\begin{array}{l}\text { Burglary/ } \\
\text { Theft }\end{array}$ & .009 & .002 & .0005 & .0006 & 0 & 0 \\
\hline $\begin{array}{l}\mathrm{N} \\
\text { (\% of total) }\end{array}$ & $\begin{array}{c}23,834 \\
(.78)\end{array}$ & $\begin{array}{c}2,960 \\
(.10)\end{array}$ & $\begin{array}{c}3,841 \\
(.13)\end{array}$ & $\begin{array}{c}4,735 \\
(.88)\end{array}$ & $\begin{array}{l}418 \\
(.08)\end{array}$ & $\begin{array}{l}231 \\
(.04)\end{array}$ \\
\hline $\begin{array}{l}\text { California: } \\
\mathrm{N} \\
\text { (\% of total) }\end{array}$ & $\begin{array}{l}1621 \\
(.47)\end{array}$ & $\begin{array}{l}573 \\
(.17)\end{array}$ & $\begin{array}{l}1231 \\
(.34)\end{array}$ & $\begin{array}{c}350 \\
(.73)\end{array}$ & $\begin{array}{c}84 \\
(.18)\end{array}$ & $\begin{array}{c}43 \\
(.09)\end{array}$ \\
\hline
\end{tabular}

Source: Authors' calculations using the United States Sentencing Commission Monitoring database, 199495. 
Table 4a: Determinants of Log Sentence Length: Men Released within Six Years of Admission,

by Admission Year

(standard errors)

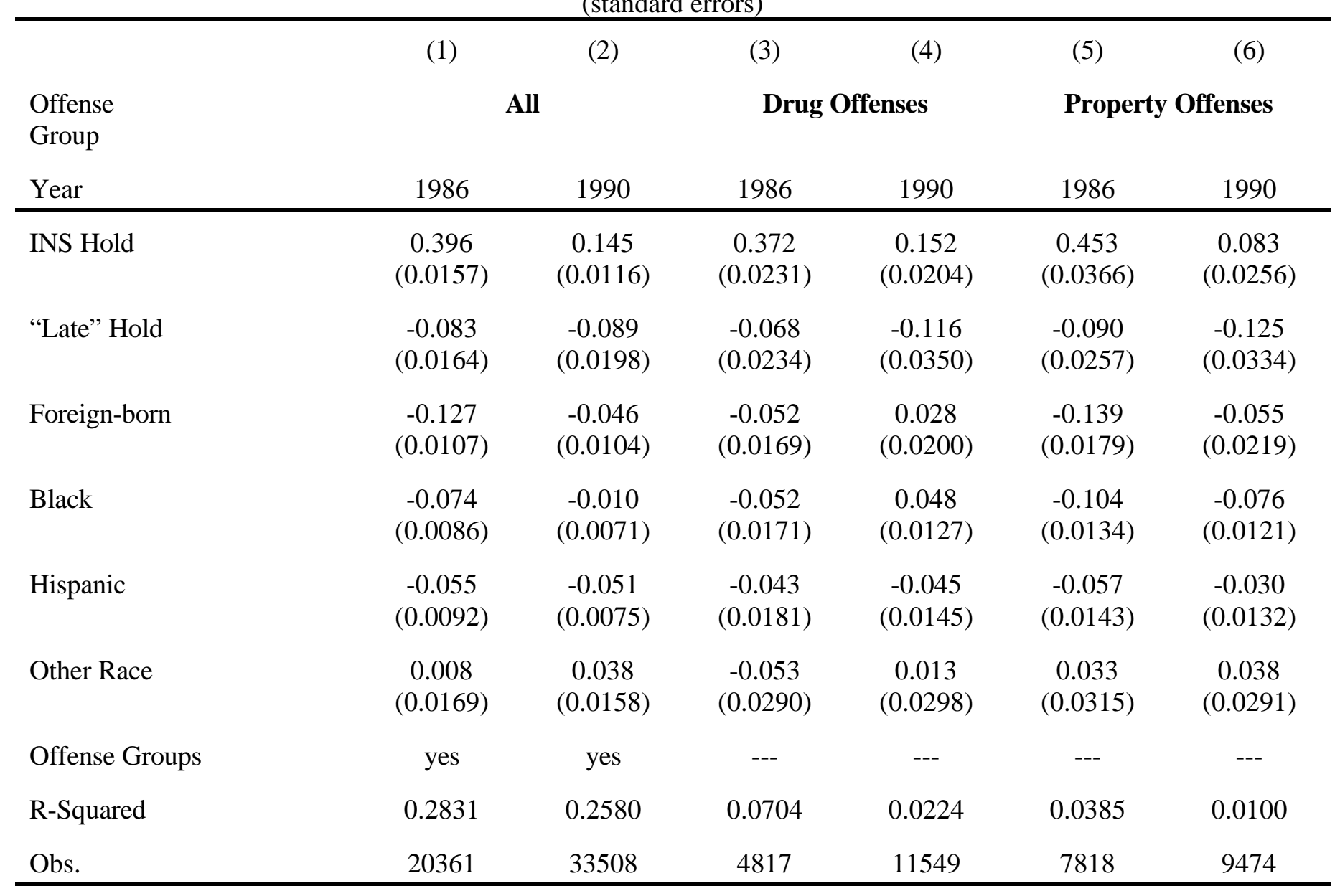

Notes: Data are from the California Department of Corrections. Men who were admitted in 1986 and 1990 and released within six years. "Late hold" indicates individuals for whom the "INS hold" was enacted after they had been released. All regressions include age at admission, its square, and a constant. The offense groups in the first two columns include: manslaughter, property assault, sex, drug, property and other offenses. 
Table 4b: Determinants of Log Sentence Length: Women Released within Six Years of Admission Admission Year 1990 (standard errors)

\begin{tabular}{lcc}
\hline & $(1)$ & $(2)$ \\
$\begin{array}{l}\text { Offense } \\
\text { Group }\end{array}$ & All & $\begin{array}{c}\text { Drug } \\
\text { Offenses }\end{array}$ \\
\hline INS Hold & 0.295 & 0.350 \\
& $(0.0540)$ & $(0.0732)$ \\
Foreign-born & -0.060 & -0.094 \\
& $(0.0373)$ & $(0.0504)$ \\
Black & 0.016 & 0.096 \\
& $(0.0174)$ & $(0.0253)$ \\
Hispanic & -0.019 & 0.053 \\
& $(0.0193)$ & $(0.0296)$ \\
Other Race & -0.022 & 0.028 \\
& $(0.0360)$ & $(0.0679)$ \\
Offense Groups & yes & --- \\
R-Squared & 0.1876 & 0.0349 \\
Obs. & 3457 & 1654 \\
\hline
\end{tabular}

Notes: See notes for previous table. The small sample sizes for women limit the specifications here and in subsequent tables. 
Table 5a. Determinants of Log Time Served: Men Released within Six Years of Admission, by Admission Year (standard errors)

\begin{tabular}{|c|c|c|c|c|c|c|c|c|c|c|c|c|}
\hline \multirow{4}{*}{$\begin{array}{l}\text { Offense } \\
\text { Group } \\
\text { Year } \\
\text { INS Hold }\end{array}$} & (1) & (2) & (3) & (4) & (5) & (6) & (7) & (8) & (9) & (10) & (11) & (12) \\
\hline & \multicolumn{8}{|c|}{ All } & \multicolumn{4}{|c|}{ Property Offenses } \\
\hline & \multicolumn{2}{|c|}{1986} & \multicolumn{2}{|c|}{1990} & \multicolumn{2}{|c|}{1986} & \multicolumn{2}{|c|}{1990} & \multicolumn{2}{|c|}{1986} & \multicolumn{2}{|c|}{1990} \\
\hline & $\begin{array}{c}0.060 \\
(0.0117)\end{array}$ & $\begin{array}{c}0.508 \\
(0.0209)\end{array}$ & $\begin{array}{c}0.061 \\
(0.0095)\end{array}$ & $\begin{array}{c}0.228 \\
(0.0160)\end{array}$ & $\begin{array}{c}0.038 \\
(0.0215)\end{array}$ & $\begin{array}{c}0.452 \\
(0.0331)\end{array}$ & $\begin{array}{c}0.058 \\
(0.0193)\end{array}$ & $\begin{array}{c}0.239 \\
(0.0295)\end{array}$ & $\begin{array}{c}0.077 \\
(0.0261)\end{array}$ & $\begin{array}{c}0.594 \\
(0.0502)\end{array}$ & $\begin{array}{c}0.131 \\
(0.0251)\end{array}$ & $\begin{array}{c}0.226 \\
(0.0390)\end{array}$ \\
\hline "Late" Hold & $\begin{array}{c}0.009 \\
(0.0160)\end{array}$ & $\begin{array}{c}-0.086 \\
(0.0236)\end{array}$ & $\begin{array}{c}-0.063 \\
(0.0265)\end{array}$ & $\begin{array}{c}-0.164 \\
(0.0361)\end{array}$ & $\begin{array}{c}-0.035 \\
(0.0264)\end{array}$ & $\begin{array}{c}-0.110 \\
(0.0364)\end{array}$ & $\begin{array}{c}-0.081 \\
(0.0430)\end{array}$ & $\begin{array}{c}-0.220 \\
(0.0621)\end{array}$ & $\begin{array}{c}0.052 \\
(0.0269)\end{array}$ & $\begin{array}{c}-0.050 \\
(0.0374)\end{array}$ & $\begin{array}{c}-0.092 \\
(0.0638)\end{array}$ & $\begin{array}{c}-0.235 \\
(0.0775)\end{array}$ \\
\hline Foreign-born & $\begin{array}{c}-0.033 \\
(0.0104)\end{array}$ & $\begin{array}{c}-0.176 \\
(0.0154)\end{array}$ & $\begin{array}{c}-0.034 \\
(0.0097)\end{array}$ & $\begin{array}{c}-0.086 \\
(0.0151)\end{array}$ & $\begin{array}{c}0.007 \\
(0.0153)\end{array}$ & $\begin{array}{c}-0.051 \\
(0.0231)\end{array}$ & $\begin{array}{c}-0.025 \\
(0.0213)\end{array}$ & $\begin{array}{c}0.008 \\
(0.0305)\end{array}$ & $\begin{array}{c}-0.038 \\
(0.0202)\end{array}$ & $\begin{array}{c}-0.197 \\
(0.0268)\end{array}$ & $\begin{array}{c}-0.079 \\
(0.0240)\end{array}$ & $\begin{array}{c}-0.142 \\
(0.0350)\end{array}$ \\
\hline $\ln ($ sentence $)$ & $\begin{array}{c}1.361 \\
(0.0711)\end{array}$ & -- & $\begin{array}{c}1.711 \\
(0.0788)\end{array}$ & -- & $\begin{array}{c}1.011 \\
(0.1628)\end{array}$ & -- & $\begin{array}{c}1.76 \\
(0.0838)\end{array}$ & -- & $\begin{array}{c}1.085 \\
(0.1443)\end{array}$ & -- & $\begin{array}{c}1.332 \\
(0.0989)\end{array}$ & -- \\
\hline $\ln (\text { sentence })^{2}$ & $\begin{array}{c}-0.032 \\
(0.0096)\end{array}$ & -- & $\begin{array}{c}-0.080 \\
(0.0110)\end{array}$ & -- & $\begin{array}{c}0.015 \\
(0.0236)\end{array}$ & -- & $\begin{array}{c}-0.082 \\
(0.0113)\end{array}$ & -- & $\begin{array}{c}0.008 \\
(0.0201)\end{array}$ & -- & $\begin{array}{c}-0.028 \\
(0.0135)\end{array}$ & -- \\
\hline Black & $\begin{array}{c}0.006 \\
(0.0066)\end{array}$ & $\begin{array}{c}-0.079 \\
(0.0118)\end{array}$ & $\begin{array}{c}-0.016 \\
(0.0058)\end{array}$ & $\begin{array}{c}-0.027 \\
(0.0100)\end{array}$ & $\begin{array}{c}-0.027 \\
(0.0158)\end{array}$ & $\begin{array}{c}-0.085 \\
(0.0248)\end{array}$ & $\begin{array}{c}-0.043 \\
(0.0109)\end{array}$ & $\begin{array}{c}0.018 \\
(0.0187)\end{array}$ & $\begin{array}{c}0.011 \\
(0.0113)\end{array}$ & $\begin{array}{c}-0.107 \\
(0.0191)\end{array}$ & $\begin{array}{c}-0.009 \\
(0.0116)\end{array}$ & $\begin{array}{c}-0.097 \\
(0.0181)\end{array}$ \\
\hline Hispanic & $\begin{array}{c}0.022 \\
(0.0077)\end{array}$ & $\begin{array}{c}-0.040 \\
(0.0128)\end{array}$ & $\begin{array}{c}0.022 \\
(0.0060)\end{array}$ & $\begin{array}{c}0.037 \\
(0.0103)\end{array}$ & $\begin{array}{c}-0.031 \\
(0.0172)\end{array}$ & $\begin{array}{c}-0.079 \\
(0.0259)\end{array}$ & $\begin{array}{c}-0.010 \\
(0.0126)\end{array}$ & $\begin{array}{c}-0.061 \\
(0.0212)\end{array}$ & $\begin{array}{c}0.029 \\
(0.0129)\end{array}$ & $\begin{array}{c}-0.037 \\
(0.0204)\end{array}$ & $\begin{array}{c}0.030 \\
(0.0112)\end{array}$ & $\begin{array}{c}-0.004 \\
(0.0185)\end{array}$ \\
\hline Other Race & $\begin{array}{c}0.001 \\
(0.0126)\end{array}$ & $\begin{array}{c}0.009 \\
(0.0226)\end{array}$ & $\begin{array}{c}-0.007 \\
(0.0120)\end{array}$ & $\begin{array}{c}0.036 \\
(0.0203)\end{array}$ & $\begin{array}{c}-0.027 \\
(0.0260)\end{array}$ & $\begin{array}{c}-0.085 \\
(0.0402)\end{array}$ & $\begin{array}{c}-0.002 \\
(0.0203)\end{array}$ & $\begin{array}{c}0.017 \\
(0.0392)\end{array}$ & $\begin{array}{c}0.019 \\
(0.0220)\end{array}$ & $\begin{array}{c}0.057 \\
(0.0415)\end{array}$ & $\begin{array}{c}-0.021 \\
(0.0296)\end{array}$ & $\begin{array}{c}0.022 \\
(0.0454)\end{array}$ \\
\hline Offense Groups & Yes & Yes & Yes & Yes & -- & -- & -- & -- & -- & -- & -- & -- \\
\hline R-squared & 0.7493 & 0.2096 & 0.7380 & 0.1841 & 0.6269 & & 0.6834 & 0.0243 & 0.6589 & 0.0313 & 0.6160 & 0.0169 \\
\hline Obs. & 20361 & 20361 & 33508 & 33508 & 4817 & & 11549 & 11549 & 7818 & 7818 & 9474 & 9474 \\
\hline
\end{tabular}

Notes: See previous table. 
Table 5b. Determinants of Log Time Served: Women Released within Six Years of Admission, Admission Year 1990

(standard errors)

\begin{tabular}{|c|c|c|c|c|}
\hline \multirow{3}{*}{$\begin{array}{l}\text { Offense } \\
\text { Group } \\
\text { INS Hold }\end{array}$} & (1) & (2) & (3) & (4) \\
\hline & \multicolumn{2}{|c|}{ All } & \multicolumn{2}{|c|}{ Drugs } \\
\hline & $\begin{array}{c}0.119 \\
(0.0651)\end{array}$ & $\begin{array}{c}0.459 \\
(0.0905)\end{array}$ & $\begin{array}{c}0.034 \\
(0.0616)\end{array}$ & $\begin{array}{r}0.445 \\
(0.0967)\end{array}$ \\
\hline Foreign-born & $\begin{array}{c}-0.114 \\
(0.0623)\end{array}$ & $\begin{array}{c}-0.183 \\
(0.0781)\end{array}$ & $\begin{array}{c}-0.038 \\
(0.0552)\end{array}$ & $\begin{array}{c}-0.148 \\
(0.0773)\end{array}$ \\
\hline $\ln ($ sentence $)$ & $\begin{array}{c}1.278 \\
(0.1589)\end{array}$ & -- & $\begin{array}{c}1.375 \\
(0.2241)\end{array}$ & -- \\
\hline $\ln (\text { sentence })^{2}$ & $\begin{array}{c}-0.018 \\
(0.0127)\end{array}$ & -- & $\begin{array}{c}-0.028 \\
(0.0308)\end{array}$ & -- \\
\hline Black & $\begin{array}{c}-0.004 \\
(0.0170)\end{array}$ & $\begin{array}{c}0.015 \\
(0.0263)\end{array}$ & $\begin{array}{c}-0.031 \\
(0.0233)\end{array}$ & $\begin{array}{c}0.084 \\
(0.0378)\end{array}$ \\
\hline Hispanic & $\begin{array}{c}0.005 \\
(0.0205)\end{array}$ & $\begin{array}{c}-0.017 \\
(0.0302)\end{array}$ & $\begin{array}{c}-0.026 \\
(0.0290)\end{array}$ & $\begin{array}{c}0.037 \\
(0.0453)\end{array}$ \\
\hline Other Race & $\begin{array}{c}0.043 \\
(0.0349)\end{array}$ & $\begin{array}{c}0.018 \\
(0.0544)\end{array}$ & $\begin{array}{c}-0.016 \\
(0.0510)\end{array}$ & $\begin{array}{c}0.018 \\
(0.0926)\end{array}$ \\
\hline Offense Groups & Yes & Yes & -- & -- \\
\hline R-squared & 0.6249 & 0.1123 & 0.6455 & 0.0282 \\
\hline Obs. & 3457 & 3457 & 1654 & 1654 \\
\hline
\end{tabular}

Notes: See previous table. 
Table 6. Determinants of Time Served: Men Who Serve Less than One Year, by Admission Year (standard errors)

\begin{tabular}{|c|c|c|c|c|c|c|c|c|c|}
\hline \multirow{3}{*}{$\begin{array}{l}\text { Offense Group } \\
\text { Year }\end{array}$} & (1) & (2) & (3) & (4) & (5) & (6) & (7) & (8) & (9) \\
\hline & & All & & \multicolumn{3}{|c|}{ Drug Offenses } & \multicolumn{3}{|c|}{ Property Offense } \\
\hline & 1986 & 1990 & 1996 & 1986 & 1990 & 1996 & 1986 & 1990 & 1996 \\
\hline INS Hold & $\begin{array}{c}-0.001 \\
(0.0120)\end{array}$ & $\begin{array}{c}0.084 \\
(0.0226)\end{array}$ & $\begin{array}{c}0.210 \\
(0.0265)\end{array}$ & $\begin{array}{c}-0.106 \\
(0.0731)\end{array}$ & $\begin{array}{c}0.066 \\
(0.0445)\end{array}$ & $\begin{array}{c}0.238 \\
(0.0558)\end{array}$ & $\begin{array}{c}0.029 \\
(0.0724)\end{array}$ & $\begin{array}{c}0.138 \\
(0.0477)\end{array}$ & $\begin{array}{c}0.245 \\
(0.0517)\end{array}$ \\
\hline "Late" Hold & $\begin{array}{c}0.016 \\
(0.0338)\end{array}$ & $\begin{array}{c}-0.083 \\
(0.0552)\end{array}$ & $\begin{array}{c}-0.664 \\
(0.1629)\end{array}$ & $\begin{array}{c}-0.104 \\
(0.0611)\end{array}$ & $\begin{array}{c}-0.092 \\
(0.0861)\end{array}$ & $\begin{array}{c}-0.793 \\
(0.3218)\end{array}$ & $\begin{array}{c}0.076 \\
(0.0469)\end{array}$ & $\begin{array}{c}-0.096 \\
(0.1051)\end{array}$ & $\begin{array}{c}-0.387 \\
(0.1758)\end{array}$ \\
\hline Foreign-born & $\begin{array}{c}-0.020 \\
(0.0227)\end{array}$ & $\begin{array}{c}-0.019 \\
(0.0232)\end{array}$ & $\begin{array}{c}-0.053 \\
(0.0273)\end{array}$ & $\begin{array}{c}0.062 \\
(0.0330)\end{array}$ & $\begin{array}{c}-0.006 \\
(0.0497)\end{array}$ & $\begin{array}{c}-0.071 \\
(0.0580)\end{array}$ & $\begin{array}{c}-0.033 \\
(0.0322)\end{array}$ & $\begin{array}{c}-0.072 \\
(0.0461)\end{array}$ & $\begin{array}{c}-0.113 \\
(0.0513)\end{array}$ \\
\hline $\ln ($ sentence $)$ & $\begin{array}{c}4.978 \\
(0.6519)\end{array}$ & $\begin{array}{c}4.157 \\
(0.9286)\end{array}$ & $\begin{array}{c}4.273 \\
(0.7082)\end{array}$ & $\begin{array}{c}7.369 \\
(1.2084)\end{array}$ & $\begin{array}{c}8.592 \\
(1.1075)\end{array}$ & $\begin{array}{c}5.600 \\
(0.7287)\end{array}$ & $\begin{array}{c}6.075 \\
(0.7070)\end{array}$ & $\begin{array}{c}6.432 \\
(0.6287)\end{array}$ & $\begin{array}{c}8.423 \\
(1.0145)\end{array}$ \\
\hline $\ln (\text { sentence })^{2}$ & $\begin{array}{c}-0.704 \\
(0.1054)\end{array}$ & $\begin{array}{c}-0.543 \\
(0.1504)\end{array}$ & $\begin{array}{c}-0.587 \\
(0.1135)\end{array}$ & $\begin{array}{c}-1.096 \\
(0.1980)\end{array}$ & $\begin{array}{c}-1.255 \\
(0.1811)\end{array}$ & $\begin{array}{c}-0.801 \\
(0.1172)\end{array}$ & $\begin{array}{c}-0.885 \\
(0.1163)\end{array}$ & $\begin{array}{c}-0.917 \\
(0.1028)\end{array}$ & $\begin{array}{c}-1.258 \\
(0.1665)\end{array}$ \\
\hline Black & $\begin{array}{c}-0.010 \\
(0.0182)\end{array}$ & $\begin{array}{c}-0.034 \\
(0.0136)\end{array}$ & $\begin{array}{c}-0.029 \\
(0.0157)\end{array}$ & $\begin{array}{c}-0.035 \\
(0.0450)\end{array}$ & $\begin{array}{c}-0.040 \\
(0.0242)\end{array}$ & $\begin{array}{c}-0.058 \\
(0.0273)\end{array}$ & $\begin{array}{c}-0.008 \\
(0.0239)\end{array}$ & $\begin{array}{c}-0.007 \\
(0.0213)\end{array}$ & $\begin{array}{c}-0.008 \\
(0.0259)\end{array}$ \\
\hline Hispanic & $\begin{array}{c}0.034 \\
(0.0208)\end{array}$ & $\begin{array}{c}0.021 \\
(0.0131)\end{array}$ & $\begin{array}{c}-0.035 \\
(0.0163)\end{array}$ & $\begin{array}{c}0.023 \\
(0.0454)\end{array}$ & $\begin{array}{c}0.016 \\
(0.0259)\end{array}$ & $\begin{array}{c}-0.038 \\
(0.0279)\end{array}$ & $\begin{array}{c}0.011 \\
(0.0281)\end{array}$ & $\begin{array}{c}0.028 \\
(0.0214)\end{array}$ & $\begin{array}{c}-0.021 \\
(0.0276)\end{array}$ \\
\hline Other Race & $\begin{array}{c}0.042 \\
(0.0340)\end{array}$ & $\begin{array}{c}-0.033 \\
(0.0367)\end{array}$ & $\begin{array}{c}-0.003 \\
(0.0366)\end{array}$ & $\begin{array}{c}0.002 \\
(0.0706)\end{array}$ & $\begin{array}{c}0.026 \\
(0.0511)\end{array}$ & $\begin{array}{c}-0.110 \\
(0.0820)\end{array}$ & $\begin{array}{c}0.045 \\
(0.0501)\end{array}$ & $\begin{array}{c}-0.054 \\
(0.0737)\end{array}$ & $\begin{array}{c}0.024 \\
(0.0556)\end{array}$ \\
\hline Offense Groups & Yes & Yes & Yes & -- & -- & -- & -- & -- & -- \\
\hline R-Squared & 0.1316 & 0.1910 & 0.1319 & 0.1379 & 0.2115 & 0.1414 & 0.1390 & 0.1751 & 0.1427 \\
\hline Obs. & 4360 & 8745 & 8808 & 1188 & 3033 & 3289 & 2238 & 3241 & 2993 \\
\hline $\begin{array}{l}\text { Marginal Effect of INS Hold on } \\
\text { being Admitted and Released in } \\
\text { the Same Year* }\end{array}$ & $\begin{array}{c}-0.025 \\
(0.0078)\end{array}$ & $\begin{array}{c}-0.016 \\
(0.0069)\end{array}$ & $\begin{array}{c}0.002 \\
(0.0063)\end{array}$ & $\begin{array}{c}-0.079 \\
(0.0173)\end{array}$ & $\begin{array}{c}-0.033 \\
(0.0109)\end{array}$ & $\begin{array}{c}0.035 \\
(0.0147)\end{array}$ & $\begin{array}{c}0.009 \\
(0.0291)\end{array}$ & $\begin{array}{c}-0.009 \\
(0.0228)\end{array}$ & $\begin{array}{c}-0.003 \\
(0.0178)\end{array}$ \\
\hline
\end{tabular}

Notes: See previous tables. Sample includes those admitted in first six months of the year and serve one year or less. * From a probit regression for whether the individual is in this short term sample. The probits include the same variables as the OLS regressions for time served. 
1. The restriction to "new admissions" means that offenders entering prisons for violating the conditions of probation or parole are not included in the sample.

2. If, for example, many of the incarcerated aliens were admitted on tourist or business visas, there would be little implication that the United States should change the number or criteria for admission of those seeking to become permanent resident aliens. Unfortunately, information on visa status is not available.

3. California's Determinate Sentencing Law (1982) requires specific terms of punishment for all offenses other than murder. The actual time served for those with indeterminate sentences is determined by a parole board.

4. In neither of these two cases do these omissions affect the substantive results. Dropping these final two categories of inmates eases the discussion of the results.

5. By 1996, over 30\% of the 18-44 year olds (male and female) in California were foreign born. (Published tabulations from the 1996 March CPS. See http://www.census.gov).

6. Smith and Edmonston (1997) show the distribution of offense types for the nation as a whole, by citizenship. Noncitizens are more likely (than citizens) to serve time for drug offenses, and less likely to serve time for property and violent offenses. Denominating by the male population aged 18 to 54 years, they find that noncitizens have incarceration rates for violent offense about half those of citizens; for property offenses, noncitizens have incarceration rates about one-third the native rate; while for drug offenses, noncitizens have double the incarceration rate of natives. (Smith and Edmonston 1997, p. 388.)

7. Technically, some in this category may be "excludable" rather than "deportable." "Exclusion" applies to those foreigners who are in the United States awaiting formal admission, such as refugees. They may be deemed excludable and returned to their country of origin.

8. The restriction excludes 2-5 percent of men and less than one percent of women. 
9. See published tabulations from the March 1996 CPS at http://www.census.gov.

10. The federal government has also been particularly interested in regulating offenses by or against federal officials or committed on federal property (DiIulio, Smith, and Saiger 1995).

11. See FAIR's web page, “Government Studies on Criminal Aliens,"at http://www.fairus.org/04111604.html.

12. The percent of noncitizens entering the prison system with immigration crimes is 26 percent. This number differs substantially from the percent of the stock of inmates since sentences for immigration offenses are generally shorter than for drug and violent offenses (Scalia 1996, Tables 9 and 12).

13. While it is constitutional to bring charges against a defendant under both sets of laws for the same act, this is rarely done in practice. For a discussion of these jurisdictional issues plus a model of the incentives for prosecutors to choose different cases in the two systems, see Glaeser, Kessler, Piehl (1998).

14. The coverage of these data is somewhat broader than statistics on the flow of inmates into the Bureau of Prisons, since some of those convicted are not sentenced to incarceration.

15. These comments were provided in personal communication from Stephen Legomsky, January 31, 1998.

16. See Borjas (1990), page 27, for a summary of early immigration restrictions. In fact, the first attempted regulation of immigration was the Aliens Act of 1798. It legalized the deportation of "any alien deemed 'dangerous' to the peace and safety of the country."

17. In fiscal year 1984, the United States budget reports the INS's total obligations to be $\$ 518,058,000$ (Appendix, United States Budget, Fiscal Year 1986, p. I-N16). By 1996, the total obligations are reported to be 2,291,000,000 (Appendix, United States Budget, Fiscal Year 1998, p. 684). In 1994, a new section was added to the INS budget entitled "Violent Crime Reduction Programs." By fiscal year 1998, the $\$ 732,251,000$ are "to remain available until expended" on programs to combat crime through immigration control. 
18. These rules create potential horizontal inequities across noncitizens depending on their state of residence. In states with longer sentences, immigrants will be more likely to meet the grounds for deportability.

19. The law gets quite complicated. According to Legomsky (1997, p. 448), "it is necessary ... to distinguish between the effective date of a change in the definition of "aggravated felony" and the effective dates of the various specific consequences of conviction of an aggravated felony."

20. The discussion of the IHP in this paragraph draws heavily from GAO (1997).

21. A GAO audit of the process found that, during the final six months of 1995,40 percent of a sample of potentially deportable foreign born inmates had an final deportation order upon release from prison and 52 percent had the process completed after release from prison. GAO estimated that $\$ 63$ million in detention costs could have been saved if the deportation process had been completed while inmates were incarcerated. (GAO 1997.)

22. McDonald reports that an assessment of practices related to identifying and processing criminal aliens in five states found "wide variations in the nature of cooperation between Federal, State, and local agencies" (McDonald 1997, p. 7).

23. In practice, the State Criminal Alien Assistance Program partially reimburses states for expenses of incarcerating certain criminal aliens (convicted of one felony or two misdemeanors). In fiscal year 1996, the reimbursement rate was 60 cents for each dollar claimed. (US Department of Justice, 1997a.)

24. In this paper, we focus on post-conviction treatment of foreigners. For discussions of differential treatment at earlier stages in the criminal justice process, see Hagan and Palloni (1997).

25. This also means that noncitizens will serve their sentences under more severe circumstances than citizens convicted of identical crimes.

26. As corrections agencies and the INS make and implement arrangements as to what constitutes "serving 
one's sentence," the extent to which criminal aliens serve more time in custody should decline.

27. While the latter will not be picked up in the analysis in this paper, the approach taken in Butcher and Piehl (1998a) does capture the institutionalization of those in deportation facilities.

28. These categories, however, are of questionable usefulness. They appear to be designed more for political than research purposes (e.g., many types of drug and sex offenses are delineated, while there are few categories of other violent and property crimes).

29. Generally, there are three sentence lengths from which a judge may choose. Adjustments to these may be made for other circumstances, such as particular characteristics of the crime (such as the use of a firearm) or particular characteristics of the defendant (such as having previous conviction for a violent crime).

30. A defense lawyer who is aware of the immigration consequences of different convictions may use these to negotiate with prosecutors. For example, knowing that a particular type of charge sets required deportation proceedings into motion, a defense attorney may bargain for slightly more time in return for a different charge. This would increase the sentence length of the "non-deportable" foreign born relative to those with INS holds. While this type of deal making does occur, immigration law is a specialty within law and court appointed defense attorneys (and their clients) are often not aware of the deportation consequences of various convictions. Also, it is unclear how acceptable such offers are to district attorneys.

31. When the log of sentence length is entered linearly, the coefficient is significantly different from one.

32. There are some examples where the selection bias would work to bias downward the impact of INS hold on time served in the short term sample. Consider the case where the reason for the impact of INS hold is purely due to bureaucratic delay. Suppose further that the prison authorities become better over time at identifying who is a deportable alien and moving them from the CADOC into INS custody and that 
bureaucratic delay is proportionately longer for shorter sentences. Then in the later period, a higher fraction of aliens under INS hold orders would be included in the short term subsample. Then, in the later period, the average proportion of sentence served will fall due to the addition of these people with longer sentences and therefore lower proportion served. 